University of Nebraska - Lincoln

DigitalCommons@University of Nebraska - Lincoln

Virology Papers

Virology, Nebraska Center for

2008

\title{
The Viral Etiology of AIDS-Associated Malignancies
}

Peter C. Angeletti

University of Nebraska-Lincoln, pangeletti2@unl.edu

Luwen Zhang

University of Nebraska-Lincoln, Izhang2@unl.edu

Charles Wood

University of Nebraska-Lincoln, cwood1@unl.edu

Follow this and additional works at: https://digitalcommons.unl.edu/virologypub

Part of the Virology Commons

Angeletti, Peter C.; Zhang, Luwen; and Wood, Charles, "The Viral Etiology of AIDS-Associated Malignancies" (2008). Virology Papers. 147.

https://digitalcommons.unl.edu/virologypub/147

This Article is brought to you for free and open access by the Virology, Nebraska Center for at DigitalCommons@University of Nebraska - Lincoln. It has been accepted for inclusion in Virology Papers by an authorized administrator of DigitalCommons@University of Nebraska - Lincoln. 
Published in final edited form in: Advances in Pharmacology 56 (2008): 509-557 (reproduced here as p. 509-550). Copyright 2008, Elsevier. Used by permission.

\title{
The Viral Etiology of AIDS-Associated Malignancies
}

\author{
Peter C. Angeletti, Luwen Zhang, and Charles Wood
}

Nebraska Center for Virology, School of Biological Sciences, University of Nebraska-Lincoln, Lincoln, Nebraska

\section{Chapter Overview}

The first documented cases of acquired immunodeficiency syndrome (AIDS) were characterized by the presence of rare Kaposi's sarcoma (KS) skin lesions. More than 10 years later, it was discovered that the causative agent of KS was a $\gamma$-herpesvirus, human herpesvirus-8 (HHV-8) (KS-associated herpesvirus, KSHV). It is now abundantly clear that cancers induced by viral agents [such as, Epstein-Barr virus (EBV) and human papillomavirus (HPV)] are exacerbated by human immunodeficiency virus (HIV) infection and subsequent immune suppression. For example, the incidence of and primary central nervous system (CNS) lymphoma (PCNSL) and Hodgkin's and high grade Bcell non-Hodgkin's lymphomas (NHL), nasopharyngeal carcinoma (NPC), anal, penile, oral, and invasive cervical carcinomas are much higher in AIDS patients. Also common in the AIDS-afflicted, are hematopoietic cancers, B- and T-cell lymphomas, myelosarcomas, lung cancers, and gastrointestinal tract cancers. The development of highly active antiretroviral therapy (HAART) has proved effective in inducing regression of PCNSL, NHL, KS, and other cancers caused by viruses, extending the life span and quality of life of AIDS patients. However, the general availability of HAART and other antiretrovirals in developing countries, where most HIV infections are reported, is still poor. Furthermore, several reports indicate that HAART is not effective in reversing HPV-induced cervical cancers, for unknown reasons. The development of the prophylactic HPV vaccine offers some hope that future generations can be protected against cervical and penile cancers. However, in countries with high rates of cervical cancers, such as in sub-Saharan Africa, the rate of HIV-positivity approaches $30 \%$, antiretrovirals are scarce, and the HPV vaccine is not available, nor would it be effective for those already infected with HPVs. Thus, better methods of surveillance and management of these malignancies in HIV-positive individuals continues to be a need.

\section{Introduction}

Since the first report of AIDS over 25 years ago, it was noted that there is a close association between HIV infection and the development of a number of cancers (Levine, 2006; Noy, 2006; Pantanowitz et al., 2006; Wood and Harrington, 2005). They include KS, Hodgkin's and high-grade B-cell NHL, anal, and invasive cervical carcinomas. In fact, AIDS was recognized in 1981 through an unusual increase in the number of cases of KS found among the young adult male having sex with male (MSM) population (Durack, 1981). Since then, increasing numbers of KS as well as other cancers were found in this population. Subsequently in 1982, the US Center for Disease Control and Prevention (CDC) included two malignancies, KS and PCNSL, as definitions for AIDS (1982). A third AIDS-associated malignancy, NHL, was also included as one of the AIDS-defining illnesses in 1987, and a fourth, the invasive cervical carcinoma was added in 1992. In addition to these four malignancies commonly found in AIDS patients, a number of other cancers have also increased substantially in the HIV-1infected immunosuppressed population. These cancers include multiple myelomas, leukemia, and leiomyosarcomas in children, oral cavity cancers, lung cancers, and Hodgkin's disease (Goedert et al., 1998; Grulich et al., 2002). Prior to the era of HAART, it has been estimated that up to $25 \%$ of all cancers in males under 45 years of age in the United States were associated with HIV and up to 30\% 
of all HIV-infected individuals will develop cancer. Especially with NHL, it has been estimated that individuals with immune deficiency have between 10- and 150-fold higher risk in developing NHL (Biggar and Rabkin, 1996; Grulich and Vajdic, 2005). Moreover, the management and prognosis of these patients were poor, mainly due to the aggressiveness of the tumors on immunosuppression, an increase in hematological toxicity due to treatment, and complications due to opportunistic infections (Kaplan et al., 1997). Treatment outcomes were shown to be poor, regardless of the types of treatment, with the response rate for AIDS-related lymphomas (ARL) of about $50 \%$ and the medium survival rate time of between 5 and 8 months (Kaplan et al., 1991; Navarro and Kaplan, 2006).

With the introduction of antiretroviral treatment in the mid-1990s, the spectrum of AIDS-associated malignancies and the epidemiology of the disease has been completely changed. There was a substantial decline in incidence of KS. It has been shown in a Swiss cohort that the standardized incidence rates for KS was 25 for those on HAART versus 239 for those that were not on treatment (Clifford et al., 2005). Similarly, changes in the incidences of ARL were observed for individuals that were on HAART. A number of studies have shown a decrease in incidence and mortality in patients with ARL (Besson et al., 2001; Kirk et al., 2001; Lee and Hurwitz, 2000; Navarro and Kaplan, 2006). The same Swiss cohort study has shown an overall decrease of HNL incidence of about $76 \%$ on HAART treatment. Similarly, for PCNSL, the impact of HAART is even more dramatic than other systemic ARL; a combination of radiotherapy with HAART had led to improvement of survival rate (Hoffmann et al., 2001; Newell et al., 2004). HAART alone has also been shown to lead to a regression of PCNSL (McGowan and Shah, 1998). In spite of the effects of HAART on ARL, similar dramatic effects have not been observed with cervical and anal cancers, and the results have been controversial. A study by the Women's Interagency HIV study group has shown an association between HAART and regression of cervical lesions (Minkoff et al., 2001), while other studies did not show such a correlation (Lillo et al., 2001; Schuman et al., 2003). Even with the successes of HAART on a number of AIDS-associated cancers, with the increase of the longevity of treated individuals and the prolonged effects of immunosuppression, it is likely that AIDS-associated malignancies will continue to be a major clinical manifestation of HIV-infected individuals. There is still a lack of widespread antiretroviral therapy in many developing countries where AIDS is epidemic and HIV continues to spread. Better tools for detection and better regimens for management of these malignancies are necessary. Moreover, a better understanding of the biology and the pathogenesis of these cancers is needed.

The mechanisms by which malignancies are induced in HIV-1 infected individuals are not exactly known. It is likely to vary with different types, but a common underlying course is a lack of immunological controls due to immunodeficiencies. In addition, several types of cancers have been linked to viral etiological agents. In fact, the three major types of cancers included as part of the AIDS-defining illnesses, such as KS, NHL, and cervical cancers, have been linked to infectious viral agents. KS primary effusion lymphomas (PEL) and Castleman's disease have been linked to HHV-8 or KSHV. NHL, PCNSL, Hodgkin's disease, and leiomyosarcoma were found to be associated with EBV. Cervical carcinoma and squamous cell neoplasm were linked to HPV. Substantial information is known about these tumors and their potential etiological agents. A number of mechanisms and viral genes were found to have transforming activities, and they may play a direct and indirect role in tumorigenesis. A better understanding on how infections by these viral agents can lead to tumors will lead to the development of methods to enhance the immune response to control these agents as well as development of therapeutic agents to treat these malignancies. The major focus of this chapter is to examine KSHV-, EBV-, and HPV-associated tumors and what is known about their potential mechanisms in cellular transformation and tumorigenesis. 


\section{Kaposi's Sarcoma}

KS was originally described by Moritz Kaposi in 1872 as an idiopathic, multiply pigmented sarcoma of the skin (Kaposi, 1872). The initiation of a KS lesion is called the patch stage of KS, and this stage is characterized by bluish red, well-demarcated, painless maculae, most often unilateral on the lower extremities. The lesion is composed of irregularly shaped vascular spaces present around preexisting vasculature. The lesion progresses into the plaque stage as these irregular spaces become lined with endothelial cells and proliferating spindle-shaped cells, presumed to be of endothelial origin. At this stage the lesion appears to be slightly elevated on the skin. The nodular stage can then develop and is characterized by a hard and solid appearance, brownish in color, and can be hyperkeratotic and ulcerative in nature. In advanced stages of KS, lesions are often bilateral and may involve the entire extremity as well as mucosal tissues and present with edema in the surrounding tissue. The nodular lesion is composed of bundles of proliferating spindle-shaped cells, extravasated lymphocytes and erythrocytes in an abundance of slit-like spaces. These lesions become raised on the skin and sometimes coalesce to form large nodular masses (Friedman-Kien and Saltzman, 1990; Iscovich et al., 2000)

There are four epidemiological types of KS recognized: classic, endemic, iatrogenic, and HIV/ AIDSassociated KS. Classic KS is the disease originally described by Kaposi (Kaposi, 1872). It predominantly occurs in elderly persons, aged 50-80 years, in the Mediterranean and Eastern European regions or in persons of Jewish ancestry. It is seen primarily in men, with a male:female ratio of 10-15: 1. It is infrequently detected in children and young adults (Friedman-Kien and Saltzman, 1990). Endemic KS was first characterized in African populations from Southern and Central Africa in the early 1960s (Cook, 1962; Lothe and Murray, 1962; Oettle, 1962). Endemic KS was predominantly seen in men, with male:female ratio of 10-17: 1, a mean age of 40 years, and presented with multiple, nodular, and sometimes ulcerative lesions in a centrifugal distribution. Health was well maintained while the disease was indolent for several years and rapidly deteriorated as more aggressive lesion growth and dissemination occurred. Iatrogenic- or transplant-associated KS was first recognized in the 1960s and 1970s (Gange and Jones, 1978; Harwood et al., 1979; Kapadia and Krause, 1977; Klepp et al., 1978; Penn, 1979). It was associated with patients receiving immunosuppressive therapy, most often from organ transplant. KS lesions appeared from 2 months to 8 years after therapy. Iatrogenic KS had a male:female ratio of 2-3: 1 . The lesions were mostly localized to the skin and infrequently involved the visceral organs and often regressed when therapy was discontinued.

The fourth type of KS is the AIDS-KS. In contrast to the slow development of classic KS, lesions developed rapidly and often disseminated to several locations in the body. AIDS-KS not only involves the lower extremities and skin, but also the upper body, the head regions, and the lymph nodes. It can also disseminate to other organs, such as the spleen, the lungs, the liver, and gastrointestinal track (Hengge et al., 2002). AIDS-KS, due to its rapid dissemination, multiple organ involvement, and difficulty with treatment, can be a painful and debilitating disease (Friedman-Kien and Saltzman, 1990). Since the HIV-1/ AIDS epidemic, the patterns and clinical manifestations of KS have dramatically changed, especially in Africa. Prior to the early 1980s, Kaposi sarcoma was a rare and indolent tumor of elderly adults, primarily men (Beral, 1991; Friedman-Kien and Saltzman, 1990; Kaposi, 1872). It was extremely rare in children; but with the AIDS epidemic, KS are often seen in young children, and when present, caused a rapidly disseminated disease that failed to respond to chemotherapy and led to death within 1-3 years (Bayley, 1991; Friedman-Kien and Saltzman, 1990). 


\section{A. Viral Etiology in KS}

With the association of KS to AIDS, an infectious agent has been suspected in the development of $\mathrm{KS}$, including HIV and cytomegalovirus (CMV). A report has shown that herpesvirus-like particles were found in short-term KS tissue culture, and were subsequently identified as CMV (Giraldo et al., 1980). However, the involvement of CMV in KS has never been confirmed. In 1994, herpesvirus-like sequences were isolated from biopsy material from an AIDS-KS patient using a subtractive PCR technique called representational difference analysis (Chang et al., 1994). This technique allows the preferential amplification of DNA sequences representative of affected tissue, which is absent in normal tissue from the same individual. The sequence was found to be homologous but not identical to any known herpesviruses. Thus, the virus was named KSHV or HHV-8 since it is the eighth known HHV. KSHV DNA sequences were found only in the KS tissue but not in normal skin tissues. Soon after KSHV DNA sequences were identified, the viral DNA was detected in biopsies from all clinical forms of KS, but was absent in normal tissue (Chang and Moore, 1996; Memar et al., 1995). $\mathrm{KSHV}$ is found in all KS lesions, and is mainly located in the vascular endothelial cells and perivascular spindle-shaped cells (Li et al., 1996).

To confirm the etiological role of KSHV in KS, the presence of the virus must be detected in patients prior to the appearance of the disease. Several studies have examined this by detecting viral DNA and seroconversion prior to KS development. In HIV-1-positive patients followed before and after onset of KS, it was observed that patients with KSHV viral DNA at study entry or any time prior to KS were significantly more likely to develop KS than those who were negative for viral DNA prior to KS (Moore et al., 1996c; Whitby et al., 1995). Similarly, in HIV-1-infected patients, those that developed KS were significantly more likely to be KSHV seropositive prior to the onset of KS than those that never developed KS (Gao et al., 1996a; Melbye et al., 1998). However, it is clear that not all KSHV-infected individuals will develop KS, thus KSHV infection plays a major role, but not sufficient, for the development of KS. It is likely that other cofactors, such as immunosuppression, are required for KS development.

In addition to KS, KSHV was found to be associated with two other lymphoproliferative disorders, PEL and multicentric Castleman's disease (MCD) (Cesarman et al., 1995; Soulier et al., 1995). PEL is a very rare subtype of NHL, predominantly associated with HIV-infected individuals. PEL was first identified as a subset of body cavity-based lymphomas (BCBL), which were subsequently called PELs (Cesarman et al., 1995). This type of lymphoma is distinguished from others as having a distinctive morphology, bridging large cell immunoblastic lymphoma and anaplastic large cell lymphoma. PELs are extremely rare tumors, and estimated to be about $0.13 \%$ of all AIDS-related malignancies in AIDS patients in the United States (Mbulaiteye et al., 2002). PELs are unique as they were found to contain KSHV DNA and are most frequently found in male AIDS patients. Most PELs are coinfected with EBV and KSHV and lack c-myc gene rearrangements, and the role of EBV in this type of tumors will be described in a section. MCD, also known as multicentric angiofollicular lymphoid hyperplasia, is a very rare polyclonal B-cell lymphoproliferative disorder with vascular hyperplasia involving multiple lymphoid organs. This disease is both clinically and morphologically heterogeneous, and is defined using clinical and pathological characteristics (Soulier et al., 1995). Unlike KS, where KSHV sequences can be detected in almost all KS samples, the B cells in MCD are usually not infected. In situ hybridization studies showed that the KSHV-infected cells are mainly located in the mantel zone of the follicle and high levels of the viral homologue of the cellular cytokine vIL-6 can be detected, suggesting that uninfected cells are recruited and stimulated to grow in the affected areas (Katano et al., 2000). It is likely that KSHV may be playing an indirect role in the disease. 


\section{B. KSHV Epidemiology}

KSHV belongs to the $\gamma$-herpesvirus subfamily, which can be further subdivided into two subgroups, gamma-1 or lymphocrytovirus, and gamma-2 or rhadinovirus. EBV is the prototype gamma-1 virus and the simian herpesvirus saimiri is the prototype gamma-2 herpesvirus (Roizmann et al., 1992). KSHV is classified as a gamma-2 rhadinovirus and is the first human virus of this subfamily identified (Moore et al., 1996b). The genome of KSHV is about $165 \mathrm{~kb}$ in length, with $\sim 140 \mathrm{~kb}$ of long unique DNA surrounded by two terminal repeat regions, 25-35 kb each (Russo et al., 1996). It encodes over 80-open reading frames and has significant homology to the Rhadinovirus genus of the $\gamma$-herpesvirus subfamily, all of which are known to infect lymphocytes (Moore et al., 1996c). KSHV is the only member of the rhadinovirus genus known to infect humans, but is closely related to another human $\gamma$-herpesvirus, EBV, which belongs to the lymphocryptovirus genus. A feature of $\gamma$-herpesviruses like KSHV is its ability to incorporate or pirate host genes such as cyclin D and growth factor IL-6 into their genome (Moore et al., 1996a), and these genes can then play a role in the replication, survival, and transformation function of the virus. Deciphering the functions of these viral genes will lead to a better understanding of viral pathogenesis and oncogenesis.

Unlike most other herpesviruses, KSHV infection does not seem to be widely distributed in most populations. The detection of KSHV infection relies on the presence of antibodies against either lytic and/or latent antigens and varies among the different tests that were used in different seroprevalence studies. There are several different methodologies for the detection of antibodies to KSHV. Most of these assays are based on immunofluorescence antigen (IFA), utilizing B-cell lymphoma cell lines known to be infected with KSHV as the antigen source or based on ELISA with recombinant immunogenic proteins or peptides of KSHV. The performance of these assays can be quite variable, and could account for the differences in seroprevalence reported in different studies (Pellett et al., 2003; Rabkin et al., 1998; Tedeschi et al., 2002). In North America and Northern and Western Europe, KSHV seroprevalence in adult general population or blood donors ranges from $0 \%$ to $8 \%$ (Challine et al., 2001; de Sanjose et al., 2002; Gambus et al., 2001; Gao et al., 1996b; Goedert et al., 1998; Lennette et al., 1996; Simpson et al., 1996). In these countries, the seroprevalence of KSHV in different risk groups mirrors the incidence of AIDS-KS, with a seroprevalence rate of between $25 \%$ and $50 \%$ among homosexual men. On the contrary, the reported seroprevalence of KSHV is high in the adult general population in regions of Brazil, French Guiana, the Mediterranean basin, and Central and Southern Africa, where it ranges from $10 \%$ to over $80 \%$; these regions are considered endemic for KSHV (Cunha et al., 2005; Freitas et al., 2002; Kazanji et al., 2005; Klaskala et al., 2005; Mayama et al., 1998; Mbulaiteye et al., 2003; Olsen et al., 1998; Plancoulaine et al., 2000, 2004; Wilkinson et al., 1999). Central African countries, like the Republic of Congo, Uganda, and Zambia, also have the highest KSHV infection rates in the world (Gao et al., 1996b). Therefore, KSHV seroprevalence tracks very closely with KS, with the highest infection rate in geographic areas where classic or endemic forms of KS are more common.

\section{Viral Oncogenesis}

A common property shared between KSHV and several other members of the $\gamma$-herpesviruses, such as EBV, is their ability to cause proliferation of infected host cells and lead to neoplasm in the infected host. Infection of primary endothelial cells by KSHV has been shown to lead to morphologic and phenotypic changes of these cells that resemble the characteristics of KS spindle cells, suggesting that KSHV can lead to malignant transformation and plays a role in the pathogenesis of KS (Flore et al., 1998; Foglieni et al., 2005; Moses et al., 1999). KSHV has been shown to encode for a number of viral genes that may contribute to tumorigenesis. These genes include both unique viral genes and gene homologues of cellular genes. Some of these viral genes have transformation potential, such as 
the viral K1 gene kaposin and viral G protein-coupled receptor (vGPCR). Others are viral proteins that have homology to their cellular counterparts. These proteins may deregulate cell growth and lead to transformation. These genes include the viral IL-6, viral IL-10, viral cc-class chemokines, and viral FLICE-inhibitory protein (vFLIP). Yet there are other viral genes that are involved in maintaining viral latency such as the latency-associated nuclear antigen (LANA) and K15. These genes are involved in a number of strategies that the virus uses in sustaining viral infection in pathogenesis and in the development of malignancies. These mechanisms involved the stimulation of cell proliferation, activation of cellular gene expression, immune suppression, and modulation of immune surveillance. These viral genes may also participate indirectly via upregulation of other viral genes. A summary of the viral genes involved is shown in Table I.

The KSHV K1 gene is the first open reading frame of the viral genome. It encodes a transmembrane protein with a cytoplasmic domain containing a functional immunoreceptor tyrosine-based activation motif (ITAM) (Lagunoff and Ganem, 1997; Lee et al., 2003). ITAM motifs are known to be involved in signal transduction on ligand-receptor interaction. However, K1 signaling appears to be constitutive and may be responsible for the activation and proliferation of infected B lymphocytes by inducing phosphorylation of several cellular signal transduction proteins (Lagunoff et al., 1999; Lee et al., 1998a,b). The K1 gene was shown to have transforming activities; it transformed mouse cells in vitro and caused tumors in nude mice (Lee et al., 1998b). K1 was also found to be able to replace the transforming gene (STP) of the herpesvirus saimiri and caused immortalization of marmoset T lymphocytes (Lee et al., 1998b). Transgenic mice expressing K1 gene developed malignant plasmacytomas and these cells have elevated levels of NF- $k \mathrm{~B}$ and other cellular transcription factors, further suggesting that deregulation of normal cellular functions by K1 may lead to the development of B-cell lymphomas (Prakash et al., 2002).

The viral kaposin or open reading frame K-12 has also been found to play a role in transformation. The kaposin gene is expressed during latency but can also be induced on lytic replication (Muralidhar et al., 1998,2000;Sadler et al., 1999; Wang and Boshoff, 2005). This gene is most abundantly expressed during latency and has a complex translational pattern resulting in three different forms of the kaposin proteins, known as A, B, and C (Sadler et al., 1999). Kaposin A is a type II membrane protein, and it was shown to have transforming activities and can transform cells in vitro; the transformed cells caused tumors in nude mice (Kliche et al., 2001; Muralidhar et al., 1998,2000). Its transforming activities were linked to its interaction with a guanine nucleotide exchange factor for ARF GTP ase known as cytokesin-1 and a domain known as the LXXLL motif on the protein seems to be important for transformation (Tomkowicz et al., 2005). Kaposin B appears to play a role in cytokine release; it binds to host cell protein kinase, such as mitogen-activated protein kinase (MAPK)-associated protein kinase 2, which plays an important role in the proinflammatory p28 MAPK signaling pathway, resulting in an enhancement of inflammatory cytokine secretions to enhance the development of KS (McCormick and Ganem, 2006). Currently, nothing is known about the function of Kaposin C.

The viral GPCR is a lytic viral gene and is a homologue of the cellular IL-8 receptor except that it is constitutively expressed. It binds to the CXC and CC families of chemokines (Arvanitakis et al., 1997; Cesarman et al., 1996; Gershengorn et al., 1998). KSHV GPCR has been shown to transform cell in vitro and promote immortalization of endothelial cells and tumor formation in the presence of KSHV latent genes, suggesting that both lytic and latent genes are important during the development of KS (Arvanitakis et al., 1997; Bais et al., 2003). The signal transduction property of GPCR is important for its transforming activities. It is known to stimulate the MAPK and PI3K pathways, leading to the stimulation of a large number of cellular genes that could enhance the proliferation of KSHV-infected 
cells. Activation of vGPCR has been associated with an increase in the secretion of vascular endothelial cell growth factors (VEGF) and VEGF receptors, which leads to an induction of the angiogenic response, to enhance the growth of immortalized KSHV-infected cells both in vitro and in vivo through a paracrine pathway mediated by vGPCR (Montaner et al., 2003; Sodhi et al., 2000; Yang et al., 2000).

In addition of vGPCR, there are other viral genes that have homology to cellular homologue genes, such as the viral IL-6, viral cc-chemokines (vCCLs), and vFLIP. KSHV vIL-6 has both sequence and functional homology to the cellular IL-6, but they differ in their ability to bind to cellular receptors. Cellular IL-6 requires both the a and the pg130 subunits for binding and signaling, whereas vIL-6 requires only the pg130 subunit (Molden et al., 1997). KSHV-infected PEL MCDD cells secrete vIL-6 to support the growth of the infected cells and also protect the cells from the antiviral effects mediated by the interferon pathway (Moore et al., 1996a; Nicholas et al., 1997). Thus, vIL-6 appears not only to have the ability to support the growth of infected cells, but also can protect infected cells from the effects of interferon. In addition to vIL-6, several viral genes, K4, K4.1, and K6, encode viral homologues of the cellular CC chemokines, such as RANTES and MIP-1a (Boshoff et al., 1997). These chemokines can induce signaling transduction, enhance angiogenesis, and contribute to the tumorigenesis process (Nakano et al., 2003). The KSHV FLIP gene ORF71 is a latent viral gene which encodes the FLIP protein and is structurally most homologous to the cellular FLIP. It facilitates lymphoma cell growth by activating NF- $\kappa$ B expression and its signaling pathway, and by conferring the infected cells resistance to apoptosis (Djerbi et al., 1999; Guasparri et al., 2004; Thome et al., 1997). In addition, vFLIP was shown to induce morphological changes in primary endothelial cells to become spindle-like in shape, similar to KS tumor cells (Grossmann et al., 2006). These together with the antiapoptotic functions of vFLIP reflect two features that are known to be the hallmark of KS.

Another KSHV latently expressed protein that may contribute to neoplasm is LANA. The KSHV LANA is a nuclear phosphoprotein that is important for the maintenance of viral latency (Dittmer et al., 1998). It has been shown to bind to the terminal repeat region of the viral genome and tethered the viral episome to the host chromosome so that it can be maintained during cellular mitotic replication and segregation (Ballestas et al., 1999; Cotter et al., 2001). LANA is a multifunctional viral protein and can bind to a number of cellular proteins. It can bind to tumor suppressors p53 and $\mathrm{Rb}$ and protect infected cells from apoptosis (Friborg et al., 1999; Radkov et al., 2000). This together with its ability to upregulate $B$-catenin expression promotes S-phase entry, modulates cell cycle pathways, and contributes to the development of neoplasm (Fujimuro et al., 2003).

\section{AIDS-Associated Lymphomas}

As persons with HIV infection survive longer despite significant immunosuppression, more cases of malignancy are likely to appear. Although HIV infects T lymphocytes, AIDS-associated lymphomas are of B lymphoid origin in at least $95 \%$ of all cases described. As with other lymphomas, AIDSassociated lymphomas also fall into two broad categories: AIDS-associated Hodgkin's disease and NHL. AIDS-associated NHLs are primarily encountered in patients with more advanced HIV infection, with a low CD4 count. Although Hodgkin's disease is included in the HIV-associated lymphomas in the WHO classification, it will not be discussed in this chapter because the relation between HIV infection, AIDS, and Hodgkin's disease is unclear (Carbone and Gloghini, 2005). Whether HIV infection promotes the development of Hodgkin's disease or merely modifies its clinical progression is not yet known

Mechanistic studies have revealed that potential factors contributing to lymphoma development. Three major factors promoting the development of lymphoma are HIV-induced immunosuppres- 
sion, chronic antigenic stimulation, and cytokine overproduction. These alterations are associated with the development of oligoclonal B-cell expansions. The appearance of lymphomas is characterized by the presence of a monoclonal B-cell population displaying a variety of genetic lesions, including EBV infection, c-myc gene rearrangement, bcl-6 gene rearrangement, ras gene mutations, and p53 mutations/deletions. The number and type of genetic lesions varies according to the anatomic site and histopathology. Thus, it is apparent that more than one pathogenic mechanism is operational in the development and progression of AIDS-associated lymphomas (Carbone and Gloghini, 2005; Epeldegui et al., 2006). This chapter attempts to summarize the potential role of viral etiological factors, especially EBV, on the development of the malignancies.

A. EBV, Its Latency, and Its Role in AIDS-Associated Lymphomas

EBV is a ubiquitous human-herpesvirus that infects about $95 \%$ of the adult population worldwide. The majority of primary infections occur in early childhood and are generally asymptomatic. However, when primary infection is delayed until adolescence or adulthood, as often occurs in developed countries, it may cause infectious mononucleosis (IM), which is a self-limiting lymphoproliferative disorder characterized by increased numbers of EBV-infected B cells in peripheral blood and massive oligoclonal expansion of EBV-specific CD8 + T cells. The biologic hallmark of the EBV-cell interaction is latency. EBV establishes several latencies on infection of target cells. Three types of latency have been described, each having its own distinct pattern of EBV gene expression. Type I latency is exemplified by Burkitt's lymphoma (BL) tumors in vivo and earlier passages of cultured cell lines derived from BL biopsies. Epstein-Barr Nuclear Antigen 1 (EBNA-1) and small EBV-encoded, nonpolyadenylated nuclear RNAs (EBER-1 and -2) are expressed in this form of latency. Type II latency is exemplified by NPC and Hodgkin's disease. EBNA-1, latent membrane protein 1 (LMP-1), LMP2A, and LMP2B proteins, as well as EBERs, are expressed in type II latency. EBV transforms adult primary B cells into continually growing lymphoblastoid cell lines (LCLs) and concomitantly establishes type III latency in vitro. Nine viral proteins are expressed, including six nuclear proteins (EBNA-1, EBNA-2, EBNA-3A, EBNA-3B, EBNA-3C, and EBNA-LP) and three integral membrane proteins (LMP-1, LMP-2A, and LMP-2B) plus EBERs (Kieff, 1996; Rickinson and Kieff, 1996). Extensive mechanistic studies on EBV transformation have identified several key viral genes that contribute to the viral transformation processes. They are LMP-1, LMP-2, EBNA-1, and EBNA-2.

\section{B. Latent Membrane Protein 1 (LMP-1)}

The role of LMP-1 in EBV transformation of primary B lymphocytes is well established. LMP-1 was initially identified as a viral oncoprotein on the basis of its ability to transform rodent cells. Fibroblasts constitutively expressing LMP-1 demonstrate reduced serum requirements, increased growth in soft agar, loss of contact inhibition, and tumorigenic potential in nude mice (Dawson et al., 1990; Fahraeus et al., 1990; Wang et al., 1985). Moreover, expression of LMP-1 as a transgene in mice under the control of the immunoglobulin promoter/enhancer results in increased frequency of B-cell lymphomas, indicating that this viral protein has oncogenic properties in vivo (Kulwichit Raab-Traub). In viral transformation assays with primary B cells, deletion of LMP-1 prevents the transformation of primary B cells (Izumi et al., 1997; Kaye et al., 1993), and inhibition of LMP-1 expression in EBVtransformed cells reverts the transformed phenotypes (Kilger et al., 1998). Thus, LMP-1 is required for EBV transformation of primary B cells in vitro in tissue culture system.

LMP-1 expression alone modulates cellular gene expression that is responsible for phenotypic and functional changes associated with EBV latency. These changes include the upregulation of adhe- 
sion molecules (LFA-1, ICAM-1, LFA-3), B-cell activation markers (CD23, CD30, CD40, CD71), transcriptional factors [signal transducer and activator of transcription 1 (STAT-1), -2, IRF-7], and antiapoptotic genes (Bcl-2, BclxL, Mcl1, A20). Thus, LMP-1 appears to be a central effector of altered cell growth, survival, adhesive, invasive, and even antiviral potential in EBV-infected cells (Fries et al., 1996; Miller et al., 1995; Wang et al., 1985, 1990; Yoshizaki et al., 1998).

Extensive studies have led to some insight into the molecular mechanisms underlying the function of LMP-1. LMP-1 is an integral membrane protein with six transmembrane-spanning domains and a long C-terminal domain located in the cytoplasm (Kieff, 1996; Liebowitz et al., 1986). LMP-1 acts as a constitutively active, receptor-like molecule that does not need the binding of a ligand (Gires et al., 1997). The six transmembrane domains mediate oligomerization of LMP-1 molecules in the plasma membrane, a prerequisite for LMP-1 function (Floettmann and Rowe, 1997; Gires et al., 1997). Two regions in the C-terminus of LMP-1 have been shown to initiate signaling processes, the C-terminal activator regions 1 (CTAR-1, amino acids 194-231) and 2 (CTAR-2, amino acids 332-386) (Huen et al., 1995; Mitchell and Sugden, 1995). In a more refined analysis, several kinds of functional domains have been identified. The PXQXT domain is located within the CTAR-1 and is involved in the interaction with tumor necrosis factor receptor (TNFR)-associated factors (TRAFs), and the binding of TRAFs to LMP-1 results in the induction of the NF- $\kappa$ B and AP- 1 transcription factors. It is thus apparent that LMP-1 shares functional properties with members of the TNF-receptor superfamily, particularly CD40. Moreover, LMP-1 can partially restore the wildtype phenotype of mice deficient in CD40 (Devergne et al., 1996, 1998; Miller et al., 1997, 1998; Sandberg et al., 1997). LMP-1 also interacts with TNFR-associated death domain protein (TRADD) and receptor-interacting protein (RIP) at the C terminal (Devergne et al., 1998; Floettmann and Rowe, 1997; Izumi et al., 1997, 1999; Izumi and Kieff, 1997; Kaye et al., 1996). Interaction with these two molecules contributes the majority of the NF- $\kappa$ B activity induced by LMP-1. Also, c-Jun N-terminal kinase (JNK) is activated by CTAR-2. The domain for activation is mapped to most C-terminal amino acids and apparently overlaps the TRADD interaction domain. However, whether TRADD and TRAF2 are involved in the activation of JNK is disputed (Eliopoulos and Young, 1998; Eliopoulos et al., 1999; Kilger et al., 1998). In addition, two janus kinase 3 (JAK3) binding sites have been identified between CTAR-1 and CTAR2. JAK3 binding to the sites is responsible for the activation of STAT-1(Gires et al., 1999). However, some other experimental evidence suggests an alternative mechanism (Brennan et al., 2001; Higuchi et al., 2002; Zhang et al., 2004b). In summary, the hijacking of these cellular signaling pathways by LMP-1 is likely to contribute to the pathogenesis of most EBV-associated disorders through the simultaneous or sequential activation of signals involved in the promotion of cell activation, growth, and survival.

\section{Latent Membrane Protein 2}

The LMP-2 protein contains multiple membrane spanning domains and cytoplasmic N- and C-terminal domains and forms aggregates in the membrane of EBV-infected B cells. The N-terminal domain can bind to the tyrosine kinases Lyn and Syk through their SH2 domains (Longnecker et al., 2000). These kinases are recruited to the BCR following antigen cross-linking, and their subsequent activation stimulates downstream events resulting in B-cell differentiation and proliferation. LMP2A may work as a decoy protein sequestering Lyn and Syk to inhibit BCR signaling, which make LMP-2 an inhibitor of EBV lytic replication induced by BCR ligation (Longnecker, 2000; Longnecker et al., 2000). The property of LMP-2 may play a major role in mediating EBV persistence in vivo.

Unlike LMP-1 and EBNA-2, the LMP-2 protein is not essential for B-cell transformation in vitro. Nevertheless, the constant expression of LMP-2 in EBV-carrying memory B cells from healthy individu- 
als suggests that LMP-2 probably plays an important role in viral persistence. LMP-2 in transgenic mice model has shown that LMP-2 provides survival signals that allow immature B cells to progress through developmental checkpoints and prevent cell death. This property may be related to the ability of LMP-2A to activate the serine-threonine kinase Akt. Akt is a multifunctional mediator of phosphatidylinositol 3-kinase (PI3-K) activity. Activation of the pathway results in the constitutive delivery of an antiapoptotic signal. Akt is also involved in the control of B-cell proliferation because chemical inhibition of PI3-K induced growth arrest of EBV-transformed B cells (Brennan et al., 2002).

D. Epstein-Barr Nuclear Antigen

The EBNA-1 protein is expressed in all EBV latency states and all EBV-associated tumors. The only exception is that EBNA-1 is hardly detectable in the circulating EBV-infected memory B cells. This alone suggests that the biologic properties of this protein are critical for EBV-mediated transformation (Kieff, 1996). EBV establishes itself efficiently in infected B lymphocytes, where it exists as 165 $\mathrm{kb}$, circular episome which is duplicated once per cell cycle. Remarkably only EBNA-1 protein is required for the synthesis and partitioning of the viral episomes. EBNA-1 binds to two regions of the viral origin of replication (OriP), referred to as the family of repeats (FR) and the dyad symmetry (DS) element. FR is essential for episome maintenance, while DS is required for initiation of OriP-dependent DNA replication. EBNA-1 is also a transcriptional regulator that modulates the activity of the viral promoters: $\mathrm{Wp}$ and $\mathrm{Cp}$ and its own latent promoter Qp. Moreover, EBNA-1 is essential to drive transcription of EBV's transforming genes after infection of primary B lymphocytes (Altmann et al., 2006). In addition, EBNA-1 can inhibit apoptosis in B cells that likely contributes to the persistence of EBV-infected cells and survival of EBV-transformed cells in vivo.

\section{E. EBNA-2}

The EBNA-2 protein is localized in the nucleus and is one of the first viral proteins expressed during EBV infection of primary B lymphocytes. In cooperation with EBNA-LP (also known as EBNA5), EBNA-2 induces the transition of resting B cells from G0 to G1. EBNA-2 is a key regulator of viral gene expression, being able to stimulate transcription from the major latency BamHI-C promoter, which directs expression of all the EBNA genes, and the promoters of LMP-1 and LMP-2. In addition, EBNA-2 modulates the transcriptional activity of some cellular genes. Cellular C-fgr, c-myc, CD21, CD23, and EBI1/BLR2 are upregulated whereas the immunoglobulin heavy chain genes are repressed in lymphocytes. There is no evidence that EBNA-2 binds to DNA directly. Rather, its transcriptional activity is mainly mediated by its interaction with the DNA-binding cellular protein RBPJk (also called RBP-J, CBF1, KBF2, or CSL). EBNA-2 is essential for EBV-induced immortalization of B lymphocytes and complex formation with RBP-Jk is crucial for such activity. RBP-Jk is expressed ubiquitously and is an important component of the Notch signaling pathway that is involved in the regulation of lymphoid development. Notch proteins are a family of transmembrane receptors that on ligand binding undergo proteolytic cleavage of their intracellular domain (Notch1 IC). The cleaved and released Notch1 IC fragment is transported to the nucleus where it interacts with RBPJk and modulates the activity of target promoters. Although Notch1 IC and ENBA-2 share the ability to transactivate genes by interacting with RBP-Jk, the set of promoters regulated by Notch1 IC and EBNA-2 is overlapping but not identical.

Generally, transformation of a cell requires multiple molecular events (Cole and McMahon, 1999; Kelekar and Cole, 1986; Kohl and Ruley, 1987; Ralston, 1991; Shalloway et al., 1987; Weinberg, 1985, 1989). Several viral genes, such as LMP-1 and EBNA-2, are required for the transformation of primary B cells in vitro and are believed to drive EBV transformation process in vivo. EBV contributes to the cellular transformation processes through the activity of viral proteins that act cooperatively to 
modify cellular gene expression that involved in cell proliferation, apoptosis, angiogenesis, immune regulation, and signal transduction (Cahir-McFarland et al., 2000; Chen et al., 2003; Fries et al., 1996; Henderson et al., 1991; Miller et al., 1995; Wang et al., 1985, 1990; Yoshizaki et al., 1998; Zhang and Pagano, 1999; Zhang et al., 2004a,c).

\section{AIDS-Associated NHL}

AIDS-associated NHL is generally divided into three subtypes: PCNSL, PEL ("body cavity"), and systemic NHL (Knowles, 2003). The vast majority of AIDS-associated NHL is clinically aggressive Bcell-derived neoplasms. Approximately $80 \%$ arise systemically (nodal and/or extranodal), and the remaining $15-20 \%$ arise as PCNSL. A small proportion is BCBLs (Knowles, 2003). EBV apparently contributes to the development of these tumors in various fashions.

\section{A. Primary Central Nervous System Lymphoma}

PCNSL is a form of NHL arising within and confined to the CNS. It was first described by Bailey in 1929 as a perithelial sarcoma (Bailey, 1929). Subsequent classifications have included reticulum cell sarcoma and microglioma. Improvements in histopathology and immunohistochemical techniques definitively established the lymphoid nature of PCNSL. PCNSL accounts for up to $15 \%$ of NHLs in HIV-infected patients compared to only $1 \%$ of NHLs in the general population. The reported incidence of PCNSL in HIV-infected patients is 2-6\% (at least 1000 times higher than in the general population) and has been as high as $10 \%$ in autopsy series. Although CNS involvement also occurs in AIDS-associated systemic lymphoma in the form of secondary spread of the tumor to the meninges, the disease is limited to the CNS in PCNSL (Cheung, 2004; Cingolani et al., 2005; Eichler and Batchelor, 2006; Gates and Kaplan, 2002; Sparano, 2003). Prior to the introduction of HAART, the incidence of PCNSL in the HIV-infected population was continuing to rise. However, the impact of these new drug regimens on the CD4 count may result in a decline in PCNSL, as the susceptibility to PCNSL is inversely proportional to the CD4 count (Sparano et al., 1999). In normal individuals, a small number of circulating B cells enter the CNS, and may do so in increased numbers as HIV infection advances (Cingolani et al., 2005; Ivers et al., 2004). EBV establishes latent, life-long infection in over 90\% of adults. During the course of HIV infection, EBV-specific T cells progressively lose the capacity to produce interferon-gamma in response to EBV peptides. In addition, EBV-positive B lymphocytes occur more frequently in the CNS of HIV-infected individuals than in normal brains, which may set up a stage for EBV transformation of these infected cells.

EBV appears to play a major pathogenetic role in AIDS-associated PCNSL: (1) EBV genome within tumors is present in more than $95 \%$ of AIDS patients, but in only $0-20 \%$ (probably $<5 \%$ ) of immunocompetent patients. (2) More than half of AIDS PCNSL examined so far expressed at least EBNA-2, LMPs, and EBERs, a pattern referred to as type III latency and closely resembling that seen in transformation of primary B lymphocytes in vitro EBV (Cingolani et al., 2005; Ivers et al., 2004). Expression of type III latency genes leads to a variety of cellular effects, including upregulation of the genes that are involved in transformation, such Bcl-2 and IRF-7, and inactivation of the p53 and Rb tumor suppressor gene products. It is believed that the EBV triggers certain PCNSL in vivo in a process similar to transformation processes of primary B cells in vitro (Pagano, 1999).

B. Primary Effusion Lymphoma

PELs, also known as BCBL, are B-cell NHLs and most frequently occur in AIDS patients as lym- 
phomatous effusions in the serous cavities without a detectable solid tumor mass. In the setting of AIDS, the clinical course for most of these lymphomas is extremely aggressive, with a mean survival from diagnosis of 5-7 months (Nador et al., 1996). While PELs are almost universally KSHV positive, the majority of PELs have concomitant EBV infection (reviewed in Dourmishev et al., 2003; Drexler et al., 1998; Moore and Chang, 2001). EBV apparently establishes levels type II latency in PELs with low of LMP-1 expression (Callahan et al., 1999; Fassone et al., 2000; Horenstein et al., 1997; Lacoste et al., 2000).

Both KSHV and EBV are oncogenic herpesviruses. It is thus interesting to examine if there are any interactions between the two viruses in PELs. Comparing to KSHV-only PELs, coinfection with EBV enhances the tumorigenecity of the dually infected PELs in severe combined immunodeficiency (SCID) mice model (Trivedi et al., 2004). The mechanism of the enhancement is currently unknown. However, LMP-1 might be involved in the enhancement because LMP-1 is expressed and its expression may be enhanced by both KSHV latent gene (LANA) and lytic gene (K-RTA). Although expression of LMP-1 at least in some of the PEL specimens strongly suggests the contribution of EBV to the development of the tumor, this enhancement was not apparent in clinical settings, possibly due to the fact that patients with PEL are usually at advanced HIV-infection stage.

At molecular levels, unique sets of cellular genes are expressed in dually infected, but not singly KSHV-infected PELs (Fan et al., 2005). KSHV reduces the expression of EBV EBNA-1 and represses EBV EBNA-2 activation (Krithivas et al., 2000). EBV inhibits KSHV lytic replication, in part, because of a regulatory loop in which KSHV lytic gene induces EBV LMP-1, and LMP-1, in turn, inhibits the lytic gene expression programs of KSHV (Xu et al., 2007). Like EBV EBNA-2, KSHV replication and transcriptional activator (K-RTA) bind to RBP-Jk (Liang et al., 2002), a key cellular target of the EBV latent transforming program (Zimber-Strobl and Strobl, 2001). Also, KSHV induces the expression of CD21, the cellular receptor for EBV, and thus facilitates EBV infection (Chang et al., 2005). All this data suggests that coordinated cellular transformation by the two viruses is a possibility. However, how these two viruses interact and affect each other and the pathobiology of PELs remains to be determined.

\section{Systemic AIDS-Associated NHL}

Systemic AIDS-associated NHLs are aggressive B-cell lymphomas of high or intermediate grade and heterogeneous in nature. Approximately one-third can be classified as small noncleaved cell lymphomas, which are Burkitt or Burkitt-like lymphomas. The remaining two-thirds of the lymphomas are diffuse large cell lymphomas, which are immunoblastic lymphomas or large noncleaved cell lymphomas (Brockmeyer and Barthel, 1998). EBV infection and c-myc oncogene rearrangements are the two well-established factors in the pathogenesis of the systemic NHL. The diffuse large cell lymphomas frequently express EBV latency type III antigens including EBNA-2 and LMP-1 and -2 , which have transforming activity in vitro are well established. EBV establishes type I latency expressing only EBNA-1 in BLs. However, the EBV genome can be detected in only $60 \%$ of the diffuse large cell lymphomas, and in around $30 \%$ of the AIDS-associated BLs. Because EBV is less frequently detected in systemic and lymphomas, and the increasing incidence type of this of cancer in HIV-infected patients, some additional common latent or chronic viral infections may be involved in the development of these tumors (Mueller, 1999; Shibata et al., 1993). In the setting of underlying HIV infection, systemic NHL truly behaves as an opportunistic neoplasm, overwhelming those immune mechanisms that may normally attempt to keep the cancer in check. 


\section{HPV-Associated Cancers}

\section{A. Types of HPV-Induced Cancers}

HPVs infect the stratified epithelia of skin or mucosa, where they cause benign warts. Of the 200 different types of HPVs (Cates and Dallabetta, 1999), the most common HPVs (types 2 and 4) are those that cause warts on the hands and feet of affected individuals (Howley, 1996). Anogenital tract HPVs, of which $\sim 40$ have been identified, are divided into those which confer a "low risk" (types 6, 11, 42) or a "high risk" (types 16, 18, 31) for cervical cancer (Howley, 1996; Sakai et al., 1996; zur Hausen, 1999, 2000). Studies performed by Harold Zur Hausen's laboratory provided the first definitive evidence that HPVs were present in genital cancers (Bosch et al., 1991; Durst et al., 1983; Gissmann et al., 1984; Schwarz et al., 1985; zur Hausen, 1999, 2000; zur Hausen et al., 1975, 1981). After more than 20 years of work, HPVs are now recognized as a necessary cause in $95 \%$ of invasive cervical cancers worldwide (Walboomers et al., 1999). Approximately 20 million US adults are infected with genital HPVs and there are 5.5 million new infections each year, representing a major public health concern (Cates and Dallabetta, 1999). In human cervical cancer cells, high-risk papillomavirus DNA is most often found integrated into the host chromosomes (Londesborough et al., 1996; Schwarz et al., 1985; Yee et al., 1985b).

HPVs are most commonly associated with cervical cancer, although, it is now known that many cancers are induced by HPV, including penile, anal, oral, and conjunctival cancers (Durst et al., 1983; Koutsky, 1997; Newton et al., 2002; Syrjanen, 2003; Waddell et al., 1996). High-risk HPVs have also been implicated recently in $\sim 30 \%$ of oral cancers (Gillison et al., 2000). In fact, HPVs are responsible for cancers in the tonsils, the palate, gums, tongue, and the larynx (Aaltonen et al., 2005; de Villiers et al., 1986; El-Mofty and Lu, 2003; Lopez Amado et al., 1996; Milde-Langosch et al., 1989; Mineta et al., 1998; Sinclair et al., 2005; Syrjanen, 2005; Yoshpe, 1995). High-risk HPVs have been further implicated in upper respiratory tract and lung cancers (Cheah and Looi, 1998; Clarke et al., 1991; de Villiers et al., 1986). Furthermore, evidence suggests that some digestive cancers are also HPV positive (Milde-Langosch et al., 1989; Nakano, 1994). HPVs are some of the most ubiquitous and stable viruses in nature, thus, it is not surprising that multiple tissues are targets of HPV-induced tumorigenesis.

Penile cancers are much less common than cancers of the cervix, for reasons that are not entirely clear (Gloeckler Ries et al., 2003). Despite the fact that men seldom show clinical signs, it is likely that many could be persistently infected and that the progression to penile cancer occurs under immunosuppressive conditions. Cancers of the vulva and vagina are also relatively rare compared to cervical cancers. The reason for these differences in incidence of cancers in different tissues is related to the cell-type infected. The cells of the cervical transformation zone at the squamous and columnar cell junction are the most susceptible to HPV-induced cell transformation (Jastreboff and Cymet, 2002; Jordan and Monaghan, 2004; Ponten and Guo, 1998). An analogous cell type apparently does not exist in men. However, despite lack of studies on the subject, it would be assumed that men are transmitters of HPVs (Baldwin et al., 2003; Dunne et al., 2006; Giuliano et al., 1999). Predictably, the incidence of penile cancers increases dramatically in individuals who are HIV positive (Aboulafia and Gibbons, 2001; Arany and Tyring, 1998; Laurence, 2003; Palefsky and Barrasso, 1996; Sirera et al., 2006; von Krogh et al., 1995), which likely reflects the overall increase incidence of HPV infections detected in women.

Anal cancer is a relatively rare disease, $\sim 80 \%$ of which are HPV positive (Gloeckler Ries et al., 2003; Hankey et al., 1999; Zippin and Lum, 1993). Anal cancer amounts to about $\%$ of all digestive tract cancers. The incidence of anal cancers in women is slightly higher than in men (Gloeckler Ries et al., 2003; Hankey et al., 1999; Zippin and Lum, 1993), which could be indicative of the overall higher 
rate of HPV infection among women. It appears that the incidence of anal cancers are rising in the past 10 years, reflecting changes in sexual behavior (http:/ / seer.cancer.gov/) (Gloeckler Ries et al., 2003). The highest level of risk for anal cancer caused by HPV is associated with MSM (Piketty et al., 2004). The rate of anal cancer among HIV-negative heterosexual men is $\sim 1.3 / 100,000$, while the rate of anal cancers in HIV-negative MSM is 35/100,000. Among MSM who are HIV positive, the rate of anal cancer is twofold higher than HIV-negative MSM (Fakhry and Gillison, 2006).

HPV infections of the conjunctiva of the eye are more common than previously appreciated, although resulting HPV-induced tumors of the conjunctiva are very rare (Mincione et al., 1992, 2006; Reszec and Sulkowski, 2005;Tabrizi et al., 1997; Waddell et al., 2003). Though the incidence of eye or eye-orbit tumors in the United States is extremely low $(<1 / 100,000)$ (Gloeckler Ries et al., 2003), in African countries, conjunctival tumors are more common and are undoubtedly influenced by nutrition, additional disease burdens, but most obviously by the relatively high impact of HIV in Africa (Ateenyi-Agaba et al., 2006; Frisch et al., 2000; Goedert, 2000; Newton et al., 2002; Waddell et al., 1996, 2003).

Given the wide range of cancers caused by HPV, the recent development of an HPV vaccine provides some hope for providing protection against many of the cancers described earlier. However, vaccine efforts have concentrated on only two high-risk strains (HPV16 and HPV18) (Mao et al., 2006; Villa et al., 2005), while there are at least 15 known high-risk strains. We also have evidence that multiple regional HPV variants exist, particularly in Africa, for which, the extent of protection by the current vaccine is unknown (Calleja-Macias et al., 2004; Chan et al., 1992; Ong et al., 1993; Touze et al., 1998; Williamson et al., 1994; Xi et al., 1998). Furthermore, the distribution of high-risk HPVs varies from country to country (Calleja-Macias et al., 2004; Chan et al., 1992; De Vuyst et al., 2003; Munoz et al., 2004; Ong et al., 1993; Williamson et al., 1994; Xi et al., 1998). Therefore, it is important to take a long-range view of prevention of HPV-induced cancers by use of vaccination strategies that take into account variants.

VII. HPV - The Causative Agent

\section{A. Papillomavirus Genome Structure}

HPVs are a family of small, nonenveloped, double-strand DNA viruses that establish a persistent infection, which may remain subclinical in the skin or genital tract for up to 10-20 years, but can often cause acute warts. Papillomavirus genomes are small circular DNA of $8 \mathrm{~kb}$, which encodes eight major proteins. As is typical for DNA viruses, the immediate early genes (E6 and E7) are involved with taking over the cell cycle (Fig. 1) (Howley, 1996;Howley et al., 1989; zur Hausen, 1999,2000). Unlike more complex viruses like herpesviruses, HPVs use the strategy of replicating at low copy, and thus, do not carry their own polymerase gene. Instead, gene products encoded by E1 and E2 recruit cellular polymerase a to the viral origin (Frattini and Laimins, 1994;Howley, 1996;Howley et al., 1989;Sedman and Stenlund, 1995). The genome is simply organized into early and late genes, with only two capsid genes, L1 and L2.

The functions of the viral proteins are well established and are summarized below (Table II).

B. The HPV Life Cycle

HPVs initiate their life cycle by gaining access to basal keratinocytes of the stratified epithelium; either skin or mucosa through a site of wounding (Fig. 2). Papillomavirus DNA replication is closely coupled to the process of keratinocyte differentiation in infected squamous epithelium (reviewed in Chow and Broker, 1994). In the basal and parabasal epithelial cells, HPV is maintained as a low-copy number episome (5-50 copies per cell) that under-goes regulated DNA replication under the con- 
trol of viral and host proteins. As infected keratinocytes differentiate and enter the stratum spinosum layer of the epithelium, there is a coincident increase in concentration of E1 and E2 proteins (for review, see Shaw and Howley, 2001). Induction of vegetative replication is consistent with a mode switch from theta to rolling-circle replication mechanisms (Flores and Lambert, 1997). As a consequence of this rolling-circle DNA replication mechanism, multiple rounds of viral DNA synthesis occurs in a given S-phase of the host keratinocyte (Hoffmann et al., 2006), and an increase in copy number up to between 100 and 1,000 copies per cell. Vegetative HPV DNA replication requires the virus-encoded E1 (a DNA helicase per ATPase) and E2 (a transcriptional trans-modulator) proteins, and initiates at the E1 binding site palindrome near the 5' end of the viral long control region (Kuo et al., 1994).

\section{The HPV Capsid and the Vaccine}

Capsid assembly of HPVs occurs in the more terminally differentiated layers of the stratified epithelium (Fig. 2). HPVs have icosahedral capsids arranged in a $\mathrm{T}=7 \mathrm{~d}$ lattice (Baker et al., 1991). The capsids are made up of 360 L1 molecules organized into 72 pentamers. Disulfide bond interactions between L1 molecules are important in particle assembly and disassembly (Li et al., 1998). There are 12 L2 minor capsid proteins that are associated with the inner surface of the L1 pentamers (Belnap et al., 1996). High resolution cryoelectron microscopic structures of bovine papillomavirus (BPV) have been achieved (Baker et al., 1991); less is known about HPV structure, assembly, and uncoating. L1 expression is sufficient to allow self-assembly of virus-like particles (VLPs) in the absence of other viral components (Casini et al., 2004). However, L2, when coexpressed with L1, intercalates into L1 VLPs and appears to be required for virion infectivity (Kawana et al., 2001;Stauffer et al., 1998). Though the precise role of L2 during infection is not clear, it may nucleate L1-pentamer formation. The simple, nonenveloped icosahedral HPV virions lend themselves to vaccine development. The recently developed quadrivalent vaccine targets two high-risk HPVs (16 and 18) and two low-risk HPVs (6 and 11). However, there is little evidence of significant cross-protection against the other 14 oncogenic HPVs. Furthermore, there are at least 40 genital HPVs. Thus, the development of vaccines that have a wider cross-protection or tailoring HPV vaccines for different regions of the world will become necessary.

\section{Epidemiology of HPV and HIV/AIDS}

Epidemiological evidence gathered over several years has determined that $15-20$ of the 40 of the mucosal HPV types are associated with a higher risk of progression to cervical cancer $(24,29)$. The frequency of individual high-risk HPV types worldwide has been shown to vary in respect to major global regions such as Asia, Europe, North America, South America, and sub-Saharan Africa (5, 14, 23). The rate of genital HPVs in the United States, as detected by PCR of the L1 region, is $\sim 39.2 \%$ (Peyton et al., 2001). Estimates of the rates of HPV in Africa vary from $14 \%$ to $60 \%$ depending on the country, the coincident STDs, and the methods of detection (Czegledy et al., 1992; Gravitt et al., 2002; Hassen et al., 2003; Langley et al., 1996; Mayaud et al., 2001; Motti et al., 1996; Nzila et al., 1991; O'Farrell et al., 1989; Ong et al., 1993; Serwadda et al., 1999; St. Louis et al., 1993; Thomas et al., 2004; Waddell et al., 1996; Williamson et al., 2002). The rate of HPV infections in HIV-positive patients in Zambia are very high, though rather little data is available (Mosunjac et al., 2003; Patil et al., 1995). As a whole, sub-Saharan Africa has the among the highest rates of cervical cancer in the world (Bailie et al., 1996; Clarke and Chetty, 2002; Langley et al., 1996; ter Meulen et al., 1992; Williamson et al., 2002). The distribution of oncogenic HPVs in Africa differs from the United States and Europe. For example, studies done by Nubia Munoz have pointed out that in Nigeria, the most prevalent oncogenic HPV is HPV35, 
not HPV16, which is the most common in the United States and Europe (Thomas et al., 2004). Several studies have described HPV variants unique to Africa (Calleja-Macias et al., 2004; Chan et al., 1992; Ong et al., 1993; Williamson et al., 1994). This points to a need to further investigate HPV variants in terms of HPV pathogenesis and a potential need to expand the selection of vaccine targets.

The rates of HIV infection in urban area along a contiguous stretch from Uganda to Botswana and South Africa have continued to climb in recent years (Morison, 2001). Several studies have addressed HIV-related malignancies associated with HHV-8 (KSHV) and EBV, which are associated with increased morbidity (Ablashi et al., 1999; Contreras et al., 1997; Lazzi et al., 1998; Parkin et al., 2000; Sapp et al., 2001). Despite frequency variation, HPV16 infection has been shown to be more prevalent than any other high-risk HPV type in most regions of the world. However, HIV-positive populations have a much higher rate of HPV16 positive tumors than most HIV-negative populations $(1,2,9,18$, 28). Thus, the incidence of high-risk HPV-malignancies is amplified by HIV immune suppression.

It is clear that impaired cell-mediated and humoral immunity influences the advancement of highrisk HPVs in HIV-positive individuals. Since the pool of memory and effector T cells can be dramatically shifted in HIV-positive individuals (even those who do not have AIDS), it would be expected that a certain degree of derepression of HPV replication would occur as well as a lack of adequate surveillance preneoplastic lesions. Several studies have shown a strong and consistent association between HIV and HPV coinfection and the development of cervical intraepithelial neoplasia (CIN) and genital cancer $(7,11,13,15)$. There is evidence to show that HIV-positive women have a significantly higher rate of CIN than their counterparts and are more likely to progress to invasive carcinoma than HIV-negative women $(4,12,20)$. A recent study in Brazil has shown that a very high proportion of HIV-infected women is infected with HPV and often carries multiple HPV genotypes (15).

A relationship between the HIV and HPV pathogenesis has been investigated by several studies (Durante et al., 2003; Heard et al., 2004; Klencke and Palefsky, 2003; Massad et al., 2004; Palefsky, 1991, 2003; Piketty et al., 2003, 2004; Silverberg et al., 2002; Strickler et al., 2003; Williams et al., 1994). For example, a study by Silverberg et al. (2002) found that HIV-seropositive women were 3.2-fold more likely to present with genital warts than HIV-seronegative women. Malignancies as complications are an increasing cause of morbidity of HIV-infected individuals (Patil et al., 1995; Thomas, 2001). The EBV-induced malignancy, NHL, occurs at a rate of $2.9 \%$ in AIDS patients, 60 times the average in non-AIDS patients (Beral et al., 1991). Occurrences of AIDS-related KS still occur at elevated levels, but recent advances in detection and stage analysis has improved the prognosis for HIV-positive patients (Quinlivan et al., 2002). Likewise, an improved understanding of the HPV disease process, as it relates to HIV, is essential, since antiretroviral therapy in HIV-positive individuals has not been shown to effectively reverse HPV-related disease.

The association of malignancies, such as NHL and KS, has been recognized since the beginning of the HIV epidemic, and KS is the neoplasm most commonly found in people infected with HIV. These neoplasms are responsible for extensive morbidity and mortality. In Zambia and other subSaharan nations, cervical cancer is the most common cancer (Baay et al., 2004; Hawes et al., 2003; Xi et al., 1998, 2003). Although in Africa, public education campaigns about STDs and condoms have been instituted in urban areas, there has been little success in poorer rural areas (Agha and Kusanthan, 2003). Thus, combined with endemic HIV, a high prevalence of high-risk HPVs presents a great risk for progression of dysplasias to cancer.

Infection by high-risk HPVs, especially HPV16, can induce warts; low-grade dysplasias, CIN, CIN 1 and CIN 2 designations are reversible forms of precancerous lesions (Fig. 3). Integration of the HPV 
genome can lead to an increase of expression of E6 and E7 resulting in progression to CIN 3, which is irreversible. Accumulation of mutations in cellular genes results in permanent changes in cell character leading to invasive carcinoma in situ. Progression from a benign cervical lesion to invasive cervical cancer usually occurs years after infection.

Cervical cancer and precancerous lesions (CIN) are now the most common cancer-related affliction affecting women in sub-Saharan Africa and other developing countries in the world. The rates of cervical cancer in Africa are fourfold higher in than in North America and Europe.

E. The Mechanism of HPV-Induced Transformation and Cancer Progression

High-risk HPVs (types 16, 18, and 31 for example) are often found integrated into the host genome (Yee et al., 1985a). The integrated state of the viral genome is not supportive of the viral life cycle, but can confer a growth advantage to cells due to increased expression of E6 and E7 (Jeon et al., 1995). The common feature in cancers is the expression of E6 and E7 genes which functionally inactivate p53 and Rb, respectively (Durst et al., 1987; Howley et al., 1989; Munger et al., 1989) (Fig. 4). In oncogenic HPV strains, E6 and E7 oncoproteins can block the negative growth signaling pathways of the cell via interactions with p53 and pRB tumor suppressor proteins. As a result, high-risk HPV-infected cells proliferation become disregulated and then, transformation develops. The full-length HPV E6 genes encode a 160amino acids protein, which contains two domains including zinc binding Cys-X-X-Cys motifs. High-risk HPV E6 proteins both have antiapoptotic activities and can interfere with the antiproliferative functions of p53, the cellular tumor suppressor. For this to occur, E6 first forms a complex with a cellular ubiquitin-protein ligase E6AP, the E6/E6AP complex then acts as a p53-specific ubiquitin-protein ligase to accelerate degradation of p53. E6 is also known to induce expression of human telomerase (htert), leading to the functional outcome of increased life span of infected keratinocytes. Upregulation of htert is also hallmark of a number of human cancers. Although the mechanism by which E6 suppresses cell death is established, relatively little is known about the localization of E6 proteins and its related splice products and how this relates to these functional interactions. Furthermore, the localization of E6AP in normal and E6-expressing cells is essentially unknown. Also, unknown is whether interactions and localization changes between E6 and htert alter E6 function.

E7binds Rbfamily member proteins resulting in their displacementfromE2Fand eventualdegradation. Release of E2F allows it to freely activate S-phase related genes responsible for the G1 to S transition. Justas E6 causes inactivation of p53, allowing unchecked DNA synthesis, E7, by releasing E2F, activates the expression of genes required for cellular DNA synthesis. Even if the cellular DNA is damaged, the lack of p53 allows the cell to survive through an E7-induced S-phase and replicate the viral genome.

The rate of advancement of HPV lesions, from benign hyperplasia to carcinoma in situ, is affected by additional factors, which includes immunocompetence. HIV status, directly affects immune status which determines susceptibility to secondary infections, including HPV. In addition, progression of HPV tumors are affected by HIV status since surveillance of cancer cells is impaired. It is well established that cofactors in addition to immune status, such as alcohol, drugs, smoking, oral contraceptives, and hormone levels influence HPV infection and progression of HPV-induced cancers (Fig. 5). The ability of E6 and E7 of high-risk HPVs to inactivate p53 and pRb directly correlates with the probability to develop tumors. HPV coinfection, variants, genome integration, as well as other STDs affect the propensity for HPV-induced cancer to occur and progress.

HPV-related diseases are common causes of morbidity and mortality, both in the United States and worldwide. During the year of 2006, the American Cancer Society (ACS) estimated that there were 9,710 new cases of cervical carcinoma and 3,700 cervical cancer deaths in the United States. The ACS 
estimates that there were 4,660 new anal cancers with 660 deaths and 1,470 new penile cancers with 280 deaths (ACS, 2006). There were $\sim 6,000$ new cases of oral and pharyngeal cancers with 1,400 deaths are attributable to HPV infection. In developing countries, the second greatest cancer cause of death among women is cervical cancer. Still, there are few effective antiviral therapies for prevention or treatment of HPV-related diseases. Furthermore, while the quadrivalent VLP HPV vaccine has the longterm potential to reduce HPV-induced cancers by $70 \%$, population-based studies indicate that, until all girls are immunized prior to the onset of sexual activity, the vaccine will prevent only $30-50 \%$ of cervical malignancies. More of a concern is the lack of availability of the prophylactic vaccine in countries which are afflicted with high rates of cervical cancer. Thus, we will continue to face a great deal of cervical cancer morbidity and mortality in the years to come. We are far from eliminating the need for treatments for HPV infection and HPV-induced anogenital dysplasias and cancers. Hence, the continuing need for research into papillomavirus pathogenesis especially in the context of the ongoing HIV crisis.

\section{Conclusions}

AIDS malignancies have been a major complication of the HIV disease course, and this is likely to continue in HIV-infected individuals. In the era of HAART therapy, the survival rate of the HIV-infected individuals has increased dramatically mainly because of the suppression of HIV viral load and the restoration of the immune response. However, even though HAART appears to be effective, still only leads to partial immune reconstitution. Prolonged immunosuppression will likely lead to a resurgence of AIDS-associated cancers. This coupled with the fact that there are still over 40 million individuals living with HIV today, many of whom are located in regions of the world where HAART is still not widely available, such as the African continent. It is expected that AIDS-associated cancers will continue to pose a major challenge globally for many years to come. As described earlier in this chapter, many of the cancers associated with immunosuppressed individuals are those that were found to have viral etiology. Other than the development and refinement of effective vaccines against these viruses, as in the case of HPV, there is a need for a better understanding on the role of oncogenic viral cofactor in the disease, the potential mechanisms, the viral genes and the host immune response that are involved. This knowledge will lead to the development of better strategies that could prevent infection and the malignant transformation by these potentially oncogenic viruses.

Acknowledgments

This publication was made possible, in part, by support from the following NIH grants: PHS award CA76958, NCRR COBRE grant RR15635, and INBRE grant P20 RR016469. The authors also wish to acknowledge Ms. Dianna Wright for help with the preparation of this chapter.

References

Aaltonen LM, Cajanus S, Back L, Nieminen P, Paavonen J, Ranki A. Extralaryngeal HPV infections in male patients with adult-onset laryngeal papillomatosis. Eur Arch Otorhinolaryngol 2005; 262(9): 708-712. [PubMed: 16133466]

Ablashi D, Chatlynne L, Cooper H, Thomas D, Yadav M, Norhanom AW, Chandana AK, Churdboonchart V, Kulpradist SA, Patnaik M, Liegmann K, Masood R, et al. Seroprevalence of humanherpesvirus-8 (HHV8 ) in countries of Southeast Asia compared to the USA, the Caribbean and Africa. Br J Cancer 1999; 81(5): 893-897. [PubMed: 10555764]

Aboulafia DM, Gibbons R. Penile cancer and human papilloma virus (HPV) in a human immunodeficiency virus (HIV)-infected patient. Cancer Invest 2001; 19(3): 266-272. [PubMed: 11338884]

ACS. Cancer facts and figures. American Cancer Society; 2006. http:/ / www.cancer.org

Agha S, Kusanthan T. Equity in access to condoms in urban Zambia. Health Policy Plan 2003; 18(3): 299-305. [PubMed: 12917271] 
Altmann M, Pich D, Ruiss R, Wang J, Sugden B, Hammerschmidt W. Transcriptional activation by EBV nuclear antigen 1 is essential for the expression of EBV's transforming genes. Proc Natl Acad Sci USA 2006; 103(38): 14,188-14,193. [PubMed: 16966603]

Arany I, Tyring SK. Systemic immunosuppression by HIV infection influences HPV transcription and thus local immune responses in condyloma acuminatum. Int J STD AIDS 1998; 9(5): 268-271. [PubMed: 9639204]

Arvanitakis L, Geras-Raaka E, Varma A, Gershengorn MC, Cesarman E. Human herpesvirus KSHV encodes a constitutively active G-protein-coupled receptor linked to cell proliferation. Nature 1997; 385(6614): 347350. [PubMed: 9002520]

Ateenyi-Agaba C, Weiderpass E, Tommasino M, Smet A, Arslan A, Dai M, Katongole-Mbidde E, Hainaut P, Snijders PJ, Franceschi S. Papillomavirus infection in the conjunctiva of individuals with and without AIDS: An autopsy series from Uganda. Cancer Lett 2006; 239(1): 98-102. [PubMed: 16143449]

Baay MF, Kjetland EF, Ndhlovu PD, Deschoolmeester V, Mduluza T, Gomo E, Friis H, Midzi N, Gwanzura L, Mason PR, Vermorken JB, Gundersen SG. Human papillomavirus in a rural community in Zimbabwe: The impactofHIV co-infectiononHPV genotypedistribution.JMed Virol2004;73(3):481-485.[PubMed:15170646]

Bailey P. Intracranial sarcomatous tumors of leptomeningeal origin. Arch Surg 1929; 18: 1,359-1,402.

Bailie RS, Selvey CE, Bourne D, Bradshaw D. Trends in cervical cancer mortality in South Africa. Int J Epidemiol 1996; 25(3): 488-493. [PubMed: 8671548]

Bais C, Van Geelen A, Eroles P, Mutlu A, Chiozzini C, Dias S, Silverstein RL, Rafii S, Mesri EA. Kaposi's sarcoma associated herpesvirus $\mathrm{G}$ protein-coupled receptor immortalizes human endothelial cells by activation of the VEGF receptor-2/KDR. Cancer Cell 2003; 3(2): 131-143. [PubMed: 12620408]

Baker TS, Newcomb WW, Olson NH, Cowsert LM, Olson C, Brown JC. Structures of bovine and human papillomaviruses. Analysis by cryoelectron microscopy and three-dimensional image reconstruction. Biophys J 1991; 60(6): 1,445-1,456. [PubMed: 1663794]

Baldwin SB, Wallace DR, Papenfuss MR, Abrahamsen M, Vaught LC, Kornegay JR, Hallum JA, Redmond SA, Giuliano AR. Human papillomavirus infection in men attending a sexually transmitted disease clinic. J Infect Dis 2003; 187(7): 1,064-1,070. [PubMed: 12660920]

Ballestas ME, Chatis PA, Kaye KM. Efficient persistence of extrachromosomal KSHV DNA mediated by latency-associated nuclear antigen. Science 1999; 284(5414): 641-644. [PubMed: 10213686]

Bayley AC. Occurrence, clinical behaviour and management of Kaposi's sarcoma in Zambia. Cancer Surv 1991; 10: 53-71. [PubMed: 1821324]

BelnapDM,OlsonNH,CladelNM,NewcombWW, BrownJC,KreiderJW,ChristensenND, BakerTS.Conserved features in papillomavirus and polyomavirus capsids. J Mol Biol 1996; 259(2): 249-263. [PubMed: 8656427]

Beral V. Epidemiology of Kaposi's sarcoma. Cancer Surv 1991; 10: 5-22. [PubMed: 1821323]

Beral V, Peterman T, Berkelman R, Jaffe H. AIDS-associated non-Hodgkin lymphoma. Lancet 1991; 337 (8745): 805-809. [PubMed: 1672911]

Besson C, Goubar A, Gabarre J, Rozenbaum W, Pialoux G, Chatelet FP, Katlama C, Charlotte F, Dupont B, Brousse N, Huerre M, Mikol J, et al. Changes in AIDS-related lymphoma since the era of highly active antiretroviral therapy. Blood 2001; 98(8): 2,339-2,344. [PubMed: 11588028]

Biggar RJ, Rabkin CS. The epidemiology of AIDS-related neoplasms. Hematol Oncol Clin North Am 1996; 10(5): 997-1,010. [PubMed: 8880192]

Bosch FX, Durst M, Schwarz E, Boukamp P, Fusenig NE, zur Hausen H. The early genes E6 and E7 of cancer associated human papilloma viruses as targets of tumor suppression? Behring Inst Mitt 1991; 89: 108121. [PubMed: 1656929]

Boshoff C, Endo Y, Collins PD, Takeuchi Y, Reeves JD, Schweickart VL, Siani MA, Sasaki T, Williams TJ, Gray PW, Moore PS, Chang Y, Weiss RA. Angiogenic and HIV-inhibitory functions of KSHV-encoded chemokines. Science 1997; 278(5336): 290-294. [PubMed: 9323208]

Brennan P, Floettmann JE, Mehl A, Jones M, Rowe M. Mechanism of action of a novel latent membrane protein-1 dominant negative. J Biol Chem 2001; 2001: 1,195-1,203. [PubMed: 11031256]

Brennan P, Mehl AM, Jones M, Rowe M. Phosphatidylinositol 3-kinase is essential for the proliferation of lymphoblastoid cells. Oncogene 2002; 21(8): 1,263-1,271. [PubMed: 11850846] 
Brockmeyer N, Barthel B. Clinical manifestations and therapies of AIDS associated tumors. Eur J Med Res 1998; 3(3): 127-147. [PubMed: 9502754]

Cahir-McFarland ED, Davidson DM, Schauer SL, Duong J, Kieff E. NF-kappaB inhibition causes spontaneous apoptosis in Epstein-Barr virus-transformed lymphoblastoid cells. Proc Natl Acad Sci USA 2000; 97: 6,055-6,060. [PubMed: 10811897]

Callahan J, Pai S, Cotter M, Robertson ES. Distinct patterns of viral antigen expression in Epstein-Barr virus and Kaposi's sarcoma-associated herpesvirus coinfected body-cavity-based lymphoma cell lines: Potential switches in latent gene expression due to coinfection. Virology 1999; 262(1): 18-30. [PubMed: 10489337]

Calleja-Macias IE, Kalantari M, Huh J, Ortiz-Lopez R, Rojas-Martinez A, Gonzalez-Guerrero JF, Williamson AL, Hagmar B, Wiley DJ, Villarreal L, Bernard HU, et al. Genomic diversity of human papillomavirus-16, 18, 31, and 35 isolates in a Mexican population and relationship to European, African, and Native American variants. Virology 2004; 319(2): 315-323. [PubMed: 14980491]

Carbone A, Gloghini A. AIDS-related lymphomas: From pathogenesis to pathology. Br J Haematol 2005; 130(5): 662-670. [PubMed: 16115121]

Casini GL, Graham D, Heine D, Garcea RL, Wu DT. in vitro papillomavirus capsid assembly analyzed by light scattering. Virology 2004; 325(2): 320-327. [PubMed: 15246271]

Cates W Jr. Dallabetta G. The staying power of sexually transmitted diseases. Lancet 1999; 354 (Suppl SIV62)

Cesarman E, Chang Y, Moore PS, Said JW, Knowles DM. Kaposi's sarcoma-associated herpesvirus-like DNA sequences in AIDS-related body-cavity-based lymphomas. N Engl J Med 1995; 332(18): 1,186-1,191. [PubMed: 7700311]

Cesarman E, Nador RG, Bai F, Bohenzky RA, Russo JJ, Moore PS, Chang Y, Knowles DM. Kaposi's sarcomaassociated herpesvirus contains $\mathrm{G}$ protein-coupled receptor and cyclin D homologs which are expressed in Kaposi's sarcoma and malignant lymphoma. J Virol 1996; 70(11): 8,218-8,223. [PubMed: 8892957]

Challine D, Roudot-Thoraval F, Sarah T, Laperche L, Boisson B, Mauberquez S, Dubernet F, Rigot P, Lefrere F, Mercier B, Brossard Y, Rouet F, et al. Seroprevalence of human herpes virus 8 antibody in populations at high or low risk of transfusion, graft, or sexual transmission of viruses. Transfusion 2001; 41(9): 1,1201,125. [PubMed: 11552068]

Chan SY, Ho L, Ong CK, Chow V, Drescher B, Durst M, ter Meulen J, Villa L, Luande J, Mgaya HN. Molecular variants of human papillomavirus type 16 from four continents suggest ancient pandemic spread of the virus and its coevolution with humankind. J Virol 1992; 66(4): 2,057-2,066. [PubMed: 1312620]

Chang Y, Moore PS. Kaposi's sarcoma (KS)-associated herpesvirus and its role in KS. Infect Agents Dis 1996; 5(4): 215-222. [PubMed: 8884366]

Chang Y, Cesarman E, Pessin MS, Lee F, Culpepper J, Knowles DM, Moore PS. Identification of herpesviruslike DNA sequences in AIDS-associated Kaposi's sarcoma. Science 1994; 266(5192): 1,865-1,869. [PubMed: 7997879]

Chang H, Gwack Y, Kingston D, Souvlis J, Liang X, Means RE, Cesarman E, Hutt-Fletcher L, Jung JU. Activation of CD21 and CD23 gene expression by Kaposi's sarcoma-associated herpesvirus RTA. J Virol 2005; 79(8): 4,651-4,663. [PubMed: 15795251]

Cheah PL, Looi LM. Biology and pathological associations of the human papillomaviruses: A review. Malays J Pathol 1998; 20(1): 1-10. [PubMed: 10879257]

Chen H, Hutt-Fletcher L, Cao L, Hayward SD. A positive autoregulatory loop of LMP1 expression and STAT activation in epithelial cells latently infected with Epstein-Barr virus. J Virol 2003; 77(7): 4,139-4,148. [PubMed: 12634372]

Cheung TW. AIDS-related cancer in the era of highly active antiretroviral therapy (HAART), a model of the interplay of the immune system, virus, and cancer. "On the offensive-the Trojan Horse is being destroyed" - Part B: Malignant lymphoma. Cancer Invest 2004; 22(5): 787-798. [PubMed: 15581059]

Chow LT, Broker TR. Papillomavirus DNA replication. Intervirology 1994; 37(34): 150-158. [PubMed: 7843926] 
Cingolani A, Fratino L, Scoppettuolo G, Antinori A. Changing pattern of primary cerebral lymphoma in the highly active antiretroviral therapy era. J Neurovirol 2005; 11 (Suppl 3): 38-44. [PubMed: 16540454]

Clarke B, Chetty R. Postmodern cancer: The role of human immunodeficiency virus in uterine cervical cancer. Mol Pathol 2002; 55(1): 19-24. [PubMed: 11836442]

Clarke J, Terry RM, Lacey CJ. A study to estimate the prevalence of upper respiratory tract papillomatosis in patients with genital warts. Int J STD AIDS 1991; 2(2): 114-115. [PubMed: 1646036]

Clertant P, Seif I. A common function for polyoma virus large-T and papillomavirus E1 proteins? Nature 1984; 311(5983): 276-279. [PubMed: 6090931]

Clifford GM, Polesel J, Rickenbach M, Dal Maso L, Keiser O, Kofler A, Rapiti E, Levi F, Jundt G, Fisch T, Bordoni A, De Weck D, et al. Cancer risk in the Swiss HIV Cohort Study: Associations with immunodeficiency, smoking, and highly active antiretroviral therapy. J Natl Cancer Inst 2005; 97 (6): 425-432. [PubMed: 15770006]

Cole MD, McMahon SB. The Myc oncoprotein: A critical evaluation of transactivation and target gene regulation. Oncogene 1999; 18(19): 2,916-2,924. [PubMed: 10378688]

Contreras A, Falkler WA Jr. Enwonwu CO, Idigbe EO, Savage KO, Afolabi MB, Onwujekwe D, Rams TE, Slots J. Human herpesviridae in acute necrotizing ulcerative gingivitis in children in Nigeria. Oral Microbiol Immunol 1997; 12(5): 259-265. [PubMed: 9467378]

Cook J. The clinical features of Kaposi's sarcoma in the East African Bantu. Acta Unio Int Contra Cancrum 1962; 18: 388-393. [PubMed: 13881052]

Cotter MA 2nd, Subramanian C, Robertson ES. The Kaposi's sarcoma-associated herpesvirus latency-associated nuclear antigen binds to specific sequences at the left end of the viral genome through its carboxyterminus. Virology 2001; 291(2): 241-259. [PubMed: 11878894]

Cunha AM, Caterino-de-Araujo A, Costa SC, Santos-Fortuna E, Boa-Sorte NC, Goncalves MS, Costa FF, Galvao-Castro B. Increasing seroprevalence of human herpesvirus 8 (HHV-8) with age confirms HHV-8 endemicity in Amazon Amerindians from Brazil. J Gen Virol 2005; 86(Pt 9): 2,433-2,437. [PubMed: 16099900]

Czegledy J, Rogo KO, Evander M, Wadell G. High-risk human papillomavirus types in cytologically normal cervical scrapes from Kenya. Med Microbiol Immunol (Berl.) 1992; 180(6): 321-326. [PubMed: 1312661]

Dawson CW, Rickinson AB, Young LS. Epstein-Barr virus latent membrane protein inhibits human epithelial cell differentiation. Nature 1990; 344(6268): 777-780. [PubMed: 2158628]

de Sanjose S, Marshall V, Sola J, Palacio V, Almirall R, Goedert JJ, Bosch FX, Whitby D. Prevalence of Kaposi's sarcoma-associated herpesvirus infection in sex workers and women from the general population in Spain. Int J Cancer 2002; 98(1): 155-158. [PubMed: 11857400]

Devergne O, Hatzivassiliou E, Izumi K, Kaye K, Kleijnen M, Kieff E, Mosialos G. Association of TRAF1, TRAF2, and TRAF3 with an Epstein-Barr virus LMP1 domain important for B lymphocyte transformation: Role in NF- $\kappa$ B activation. Mol Cell Biol 1996; 16: 7,098-7,108. [PubMed: 8943365]

Devergne O, McFarland EC, Mosialos G, Izumi KM, Ware CF, Kieff E. Role of the TRAF binding site and NFkappaB activation in Epstein-Barr virus latent membrane protein 1-induced cell gene expression. J Virol 1998; 72: 7,900-7,908. [PubMed: 9733827]

de Villiers EM, Weidauer H, Le JY, Neumann C, zur Hausen H. (Papilloma viruses in benign and malignant tumors of the mouth and upper respiratory tract). Laryngol Rhinol Otol (Stuttg) 1986; 65 (4): 177-179. [PubMed: 3012230]

De Vuyst H, Steyaert S, Van Renterghem L, Claeys P, Muchiri L, Sitati S, Vansteelandt S, Quint W, Kleter B, Van Marck E, Temmerman M. Distribution of human papillomavirus in a family planning population in Nairobi, Kenya. Sex Transm Dis 2003; 30(2): 137-142. [PubMed: 12567172]

Dittmer D, Lagunoff M, Renne R, Staskus K, Haase A, Ganem D. A cluster of latently expressed genes in Kaposi's sarcoma-associated herpesvirus. J Virol 1998; 72(10): 8,309-8,315. [PubMed: 9733875]

Djerbi M, Screpanti V, Catrina AI, Bogen B, Biberfeld P, Grandien A. The inhibitor of death receptor signaling, FLICE-inhibitory protein defines a new class of tumor progression factors. J Exp Med 1999; 190(7): 1,025-1,032. [PubMed: 10510092] 
Dourmishev LA, Dourmishev AL, Palmeri D, Schwartz RA, Lukac DM. Molecular genetics of Kaposi's sarcoma-associated herpesvirus (human herpesvirus-8) epidemiology and pathogenesis. Microbiol Mol Biol Rev 2003; 67(2): 175-212. [PubMed: 12794189]table of contents

Drexler HG, Uphoff CC, Gaidano G, Carbone A. Lymphoma cell lines: in vitro models for the study of HHV8+ primary effusion lymphomas (body cavity-based lymphomas). Leukemia 1998; 12(10): 1,507-1,517. [PubMed: 9766492]

Dunne EF, Nielson CM, Stone KM, Markowitz LE, Giuliano AR. Prevalence of HPV infection among men: A systematic review of the literature. J Infect Dis 2006; 194(8): 1044-1057. [PubMed: 16991079]

Durack DT. Opportunistic infections and Kaposi's sarcoma in homosexual men. N Engl J Med 1981; 305(24): 1,465-1,467. [PubMed: 6272112]

Durante AJ, Williams AB, Da Costa M, Darragh TM, Khoshnood K, Palefsky JM. Incidence of anal cytological abnormalities in a cohort of human immunodeficiency virus-infected women. Cancer Epidemiol Biomark Prev 2003; 12(7): 638-642.

Durst M, Gissmann L, Ikenberg H, zur Hausen H. A papillomavirus DNA from a cervical carcinoma and its prevalence in cancer biopsy samples from different geographic regions. Proc Natl Acad Sci USA 1983; 80(12): 3,812-3,815. [PubMed: 6304740]

Durst M, Croce CM, Gissmann L, Schwarz E, Huebner K. Papillomavirus sequences integrate near cellular oncogenes in some cervical carcinomas. Proc Natl Acad Sci USA 1987; 84(4): 1070-1074. [PubMed: 3029760]

Eichler AF, Batchelor TT. Primary central nervous system lymphoma: Presentation, diagnosis and staging. Neurosurg Focus 2006; 21(5): E15. [PubMed: 17134117]

El-Mofty SK, Lu DW. Prevalence of human papillomavirus type 16 DNA in squamous cell carcinoma of the palatine tonsil, and not the oral cavity, in young patients: A distinct clinicopathologic and molecular disease entity. Am J Surg Pathol 2003; 27(11): 1,463-1,470. [PubMed: 14576481]

Eliopoulos AG, Young LS. Activation of the cJun N-terminal kinase (JNK) pathway by the Epstein-Barr virus-encoded latent membrane protein 1 (LMP1). Oncogene 1998; 16: 1,731-1,742. [PubMed: 9582021]

Eliopoulos AG, Blake SM, Floettmann JE, Rowe M, Young LS. Epstein-Barr virus-encoded latent membrane protein 1 activates the JNK pathway through its extreme $C$ terminus via a mechanism involving TRADD and TRAF2. J Virol 1999; 73: 1,023-1,035. [PubMed: 9882303]

Epeldegui M, Widney DP, Martinez-Maza O. Pathogenesis of AIDS lymphoma: Role of oncogenic viruses and B cell activation-associated molecular lesions. Curr Opin Oncol 2006; 18(5): 444-448. [PubMed: 16894291]

Fahraeus R, Rymo L, Rhim JS, Klein G. Morphological transformation of human keratinocytes expressing the LMP gene of Epstein-Barr virus. Nature 1990; 345: 447-449. [PubMed: 1692971]

Fakhry C, Gillison ML. Clinical implications of human papillomavirus in head and neck cancers. J Clin Oncol 2006; 24(17): 2,606-2,611. [PubMed: 16763272]

Fan W, Bubman D, Chadburn A, Harrington WJ Jr. Cesarman E, Knowles DM. Distinct subsets of primary effusion lymphoma can be identified based on their cellular gene expression profile and viral association. J Virol 2005; 79(2): 1,244-1,251. [PubMed: 15613351]

Fassone L, Bhatia K, Gutierrez M, Capello D, Gloghini A, Dolcetti R, Vivenza D, Ascoli V, Lo Coco F, Pagani L, Dotti G, Rambaldi A, et al. Molecular profile of Epstein-Barr virus infection in HHV-8-positive primary effusion lymphoma. Leukemia 2000; 14(2): 271-277. [PubMed: 10673744]

Floettmann JE, Rowe M. Epstein-Barr virus latent membrane protein-1 (LMP1) C-terminus activation region 2 (CTAR2) maps to the far C-terminus and requires oligomerization for NF- $\kappa$ B activation. Oncogene 1997; 15: 1,851-1,858. [PubMed: 9362452]

Flore O, Rafii S, Ely S, O'Leary JJ, Hyjek EM, Cesarman E. Transformation of primary human endothelial cells by Kaposi's sarcoma-associated herpesvirus. Nature 1998; 394(6693): 588-592. [PubMed: 9707121]

Flores ER, Lambert PF. Evidence for a switch in the mode of human papillomavirus type 16 DNA replication during the viral life cycle. J Virol 1997; 71(10): 7,167-7,179. [PubMed: 9311789] 
Foglieni C, Scabini S, Belloni D, Broccolo F, Lusso P, Malnati MS, Ferrero E. Productive infection of HUVEC by HHV-8 is associated with changes compatible with angiogenic transformations. Eur J Histochem 2005; 49(3): 273-284. [PubMed: 16216813]

Frattini MG, Laimins LA. Binding of the human papillomavirus E1 origin-recognition protein is regulated through complex formation with the E2 enhancer-binding protein. Proc Natl Acad Sci USA 1994; 91(26): 12,398-12,402. [PubMed: 7809048]

Freitas RB, Freitas MR, Linhares AC. Prevalence of human herpesvirus 8 antibodies in the population of Belem, Para, Brazil. Rev Inst Med Trop Sao Paulo 2002; 44(6): 309-313. [PubMed: 12532213]

Friborg J Jr. Kong W, Hottiger MO, Nabel GJ. p53 inhibition by the LANA protein of KSHV protects against cell death. Nature 1999; 402(6764): 889-894. [PubMed: 10622254]

Friedman-Kien AE, Saltzman BR. Clinical manifestations of classical, endemic African, and epidemic AIDSassociated Kaposi's sarcoma. J Am Acad Dermatol 1990; 22(6 Pt 2): 1,237-1,250. [PubMed: 2193952]

Fries KL, Miller WE, Raab-Traub N. Epstein-Barr virus latent membrane protein 1 blocks p53-mediated apoptosis through the induction of the A20 gene. J Virol 1996; 70: 8,653-8,659. [PubMed: 8970991]

Frisch M, Biggar RJ, Goedert JJ. Human papillomavirus-associated cancers in patients with human immunodeficiency virus infection and acquired immunodeficiency syndrome. J Natl Cancer Inst 2000; 92(18): 1,500-1,510. [PubMed: 10995805]

Fujimuro M, Wu FY, ApRhys C, Kajumbula H, Young DB, Hayward GS, Hayward SD. A novel viral mechanism for dysregulation of beta-catenin in Kaposi's sarcoma-associated herpesvirus latency. Natl Med 2003; 9(3): 300-306. [PubMed: 12592400]

Gambus G, Bourboulia D, Esteve A, Lahoz R, Rodriguez C, Bolao F, Sirera G, Muga R, del Romero J, Boshoff C, Whitby D, Casabona J. Prevalence and distribution of HHV-8 in different subpopulations, with and without HIV infection, in Spain. AIDS 2001; 15(9): 1,167-1,174. [PubMed: 11416719]

Gange RW, Jones EW. Kaposi's sarcoma and immunosuppressive therapy: An appraisal. Clin Exp Dermatol 1978; 3(2): 135-146. [PubMed: 699366]

Gao SJ, Kingsley L, Hoover DR, Spira TJ, Rinaldo CR, Saah A, Phair J, Detels R, Parry P, Chang Y, Moore PS. Seroconversion to antibodies against Kaposi's sarcoma-associated herpesvirus-related latent nuclear antigens before the development of Kaposi's sarcoma. N Engl J Med 1996a; 335(4): 233-241. [PubMed: 8657239]

Gao SJ, Kingsley L, Li M, Zheng W, Parravicini C, Ziegler J, Newton R, Rinaldo CR, Saah A, Phair J, Detels R, Chang Y, Moore PS. KSHV antibodies among Americans, Italians and Ugandans with and without Kaposi's sarcoma. Natl Med 1996b; 2(8): 925-928. [PubMed: 8705864]

Gates AE, Kaplan LD. AIDS malignancies in the era of highly active antiretroviral therapy. Oncology (Williston Park, N.Y.) 2002; 16(5): 657-665, discussion 665, 668-670.

Gershengorn MC, Geras-Raaka E, Varma A, Clark-Lewis I. Chemokines activate Kaposi's sarcoma-associated herpesvirus $G$ protein-coupled receptor in mammalian cells in culture. J Clin Invest 1998; 102(8): 1,469-1,472. [PubMed: 9788958]

Gillison ML, Koch WM, Capone RB, Spafford M, Westra WH, Wu L, Zahurak ML, Daniel RW, Viglione M, Symer DE, Shah KV, Sidransky D. Evidence for a causal association between human papillomavirus and a subset of head and neck cancers. J Natl Cancer Inst 2000; 92(9): 709-720. [PubMed: 10793107]

Giraldo G, Beth E, Huang ES. Kaposi's sarcoma and its relationship to cytomegalovirus (CMNV). III. CMV DNA and CMV early antigens in Kaposi's sarcoma. Int J Cancer 1980; 26(1): 23-29. [PubMed: 6263803]

Gires O, Zimber-Strobl U, Gonnella R, Ueffing M, Marschall G, Zeidler R, Pich D, Hammerschmidt W. Latent membrane protein 1 of Epstein-Barr virus mimics a constitutively active receptor molecule. EMBO J 1997; 16: 6,131-6,140. [PubMed: 9359753]

Gires O, Kohlhuber F, Kilger E, Baumann M, Kieser A, Kaiser C, Zeidler R, Scheffer B, Ueffing M, Hammerschmidt W. Latent membrane protein 1 of Epstein-Barr virus interacts with JAK3 and activates STAT proteins. EMBO J 1999; 18: 3,064-3,073. [PubMed: 10357818]

Gissmann L, Boshart M, Durst M, Ikenberg H, Wagner D, zur Hausen H. Presence of human papillomavirus in genital tumors. J Invest Dermatol 1984; 83 (Suppl 1): 26S-28S. [PubMed: 6330218] 
Giuliano AR, Papenfuss M, Schneider A, Nour M, Hatch K. Risk factors for high-risk type human papillomavirus infection among Mexican-American women. Cancer Epidemiol. Biomark Prev 1999; 8(7): 615-620.

Gloeckler Ries LA, Reichman ME, Lewis DR, Hankey BF, Edwards BK. Cancer Survival and incidence from the Surveillance, Epidemiology, and End Results (SEER) program. Oncologist 2003; 8(6): 541-552. [PubMed: 14657533]

Goedert JJ. The epidemiology of acquired immunodeficiency syndrome malignancies. Semin Oncol 2000; 27(4): 390-401. [PubMed: 10950365]

Goedert JJ, Cote TR, Virgo P, Scoppa SM, Kingma DW, Gail MH, Jaffe ES, Biggar RJ. Spectrum of AIDS-associated malignant disorders. Lancet 1998; 351(9119): 1,833-1,839. [PubMed: 9652666]

Gravitt PE, Kamath AM, Gaffikin L, Chirenje ZM, Womack S, Shah KV. Human papillomavirus genotype prevalence in high-grade squamous intraepithelial lesions and colposcopically normal women from Zimbabwe. Int J Cancer 2002; 100(6): 729-732. [PubMed: 12209615]

Grossmann C, Podgrabinska S, Skobe M, Ganem D. Activation of NF-kappaB by the latent vFLIP gene of Kaposi's sarcoma-associated herpesvirus is required for the spindle shape of virus-infected endothelial cells and contributes to their proinflammatory phenotype. J Virol 2006; 80(14): 7,179-7,185. [PubMed: 16809323]

Grulich AE, Vajdic CM. The epidemiology of non-Hodgkin lymphoma. Pathology 2005; 37(6): 409-419. [PubMed: 16373224]

Grulich AE, Li Y, McDonald A, Correll PK, Law MG, Kaldor JM. Rates of non-AIDS-defining cancers in people with HIV infection before and after AIDS diagnosis. AIDS 2002; 16(8): 1155-1161. [PubMed: 12004274]

Guasparri I, Keller SA, Cesarman E. KSHV vFLIP is essential for the survival of infected lymphoma cells. J Exp Med 2004; 199(7): 993-1,003. [PubMed: 15067035]

Hankey BF, Ries LA, Edwards BK. The surveillance, epidemiology, and end results program: A national resource. Cancer Epidemiol. Biomark Prev 1999; 8(12): 1117-1121.

Harwood AR, Osoba D, Hofstader SL, Goldstein MB, Cardella CJ, Holecek MJ, Kunynetz R, Giammarco RA. Kaposi's sarcoma in recipients of renal transplants. Am J Med 1979; 67(5): 759-765. [PubMed: 159624]

Hassen E, Chaieb A, Letaief M, Khairi H, Zakhama A, Remadi S, Chouchane L. Cervical human papillomavirus infection in Tunisian women. Infection 2003; 31(3): 143-148. [PubMed: 12789471]

Hawes SE, Critchlow CW, Faye Niang MA, Diouf MB, Diop A, Toure P, Aziz Kasse A, Dembele B, Salif Sow $\mathrm{P}$, Coll-Seck AM, Kuypers JM, Kiviat NB. Increased risk of high-grade cervical squamous intraepithelial lesions and invasive cervical cancer among African women with human immunodeficiency virus type 1 and 2 infections. J Infect Dis 2003; 188(4): 555-563. [PubMed: 12898443]

Heard I, Palefsky JM, Kazatchkine MD. The impact of HIV antiviral therapy on human papillomavirus (HPV) infections and HPV-related diseases. Antivir Ther 2004; 9(1): 13-22. [PubMed: 15040532]

Henderson S, Rowe M, Gregory C, Croom-Carter D, Wang F, Longnecker R, Kieff E, Rickinson A. Induction of bcl-2 expression by Epstein-Barr virus latent membrane protein 1 protects infected B cells from programmed cell death. Cell 1991; 65: 1,107-1,115. [PubMed: 1648447]

Hengge UR, Ruzicka T, Tyring SK, Stuschke M, Roggendorf M, Schwartz RA, Seeber S. Update on Kaposi's sarcoma and other HHV8 associated diseases. Part 1: Epidemiology, environmental predispositions, clinical manifestations, and therapy. Lancet Infect Dis 2002; 2(5): 281-292. [PubMed: 12062994]

Higuchi M, Kieff E, Izumi KM. The Epstein-Barr virus latent membrane protein 1 putative Janus kinase 3 (JAK3) binding domain does not mediate JAK3 association or activation in B-lymphoma or lymphoblastoid cell lines. J Virol 2002; 76(1): 455-459. [PubMed: 11739714]

Hoffmann C, Tabrizian S, Wolf E, Eggers C, Stoehr A, Plettenberg A, Buhk T, Stellbrink HJ, Horst HA, Jager H, Rosenkranz T. Survival of AIDS patients with primary central nervous system lymphoma is dramatically improved by HAART-induced immune recovery. AIDS 2001; 15(16): 2,119-2,127. [PubMed: 11684931]

Hoffmann R, Hirt B, Bechtold V, Beard P, Raj K. Different modes of human papillomavirus DNA replication during maintenance. J Virol 2006; 80(9): 4,431-4,439. [PubMed: 16611903] 
Horenstein MG, Nador RG, Chadburn A, Hyjek EM, Inghirami G, Knowles DM, Cesarman E. Epstein-Barr virus latent gene expression in primary effusion lymphomas containing Kaposi's sarcoma-associated herpesvirus/human herpesvirus-8. Blood 1997; 90(3): 1,186-1,191. [PubMed: 9242551]

Howley, PM. Papillomavirinae: The viruses and their replication In: Virology. 2nd ed. Lippincott-Raven Publishers; Philadelphia, PA: 1996. p. 2,045-2,076.

Howley PM, Munger K, Werness BA, Phelps WC, Schlegel R. Molecular mechanisms of transformation by the human papillomaviruses. Princess Takamatsu Symp 1989; 20: 199-206. [PubMed: 2562182]

Huen DS, Henderson SA, Croom-Carter S, Rowe M. The Epstein-Barr virus latent membrane protein-1 (LMP1) mediates activation of NF- $\kappa \mathrm{B}$ and cell surface phenotype via two effector regions in its carboxyterminal cytoplasmic domain. Oncogene 1995; 10: 549-560. [PubMed: 7845680]

Iscovich J, Boffetta P, Franceschi S, Azizi E, Sarid R. Classic Kaposi sarcoma: Epidemiology and risk factors. Cancer 2000; 88(3): 500-517. [PubMed: 10649240]

Ivers LC, Kim AY, Sax PE. Predictive value of polymerase chain reaction of cerebrospinal fluid for detection of Epstein-Barr virus to establish the diagnosis of HIV-related primary central nervous system lymphoma. Clin Infect Dis 2004; 38(11): 1,629-1,632. [PubMed: 15156453]

Izumi K, Kieff E. The Epstein-Barr virus oncogene product latent membrane protein 1 engages the tumor necrosis factor receptor-associated death domain protein to mediate B-lymphocyte growth transformation and activate NF-kB. Proc Natl Acad Sci 1997; 94: 12,592-12,597. [PubMed: 9356494]

Izumi KM, Kaye KM, Kieff ED. The Epstein-Barr virus LMP1 amino acid sequence that engages tumor necrosis factor receptor associated factors is critical for primary B lymphocyte growth transformation. Proc Natl Acad Sci USA 1997; 94: 1,447-1,452. [PubMed: 9037073]

Izumi KM, McFarland EC, Ting AT, Riley EA, Seed B, Kieff ED. The Epstein-Barr virus oncoprotein latent membrane protein 1 engages the tumor necrosis factor receptor-associated proteins TRADD and receptor-interacting protein (RIP) but does not induce apoptosis or require RIP for NF-kappaB activation. Mol Cell Biol 1999; 19: 5,759-5,767. [PubMed: 10409763]

Jastreboff AM, Cymet T. Role of the human papilloma virus in the development of cervical intraepithelial neoplasia and malignancy. Postgrad Med J 2002; 78(918): 225-228. [PubMed: 11930025]

Jeon S, Allen-Hoffmann BL, Lambert PF. Integration of human papilloma-virus type 16 into the human genome correlates with a selective growth advantage of cells. J Virol 1995; 69(5): 2,989-2,997. [PubMed: 7707525]

Jordan LB, Monaghan H. Pathology of the cervix: Recent developments. Clin Oncol (R Coll Radiol) 2004; 16(4): 248-254. [PubMed: 15214648]

Kapadia SB, Krause JR. Kaposi's sarcoma after long-term alkylating agent therapy for multiple myeloma. South Med J 1977; 70(8): 1,011-1,013. [PubMed: 887963]

Kaplan LD, Kahn JO, Crowe S, Northfelt D, Neville P, Grossberg H, Abrams DI, Tracey J, Mills J, Volberding PA. Clinical and virologic effects of recombinant human granulocyte-macrophage colony-stimulating factor in patients receiving chemotherapy for human immunodeficiency virus-associated non-Hodgkin's lymphoma: Results of a randomized trial. J Clin Oncol 1991; 9(6): 929- 940. [PubMed: 2033429]

Kaplan LD, Straus DJ, Testa MA, Von Roenn J, Dezube BJ, Cooley TP, Herndier B, Northfelt DW, Huang J, Tulpule A, Levine AM, National Institute of Allergy and Infectious Diseases AIDS Clinical Trials Group. Low-dose compared with standard-dose m-BACOD chemotherapy for non-Hodgkin's lymphoma associated with human immunodeficiency virus infection. N Engl J Med 1997; 336(23): 1,641-1,648. [PubMed: 9171066]

Kaposi M. Idiopathic multiple pigmented sarcoma of the skin. Arch. Dermatol. Syphilis 1872; 4: 265- 273.

Katano H, Sato Y, Kurata T, Mori S, Sata T. Expression and localization of human herpesvirus 8-encoded proteins in primary effusion lymphoma, Kaposi's sarcoma, and multicentric Castleman's disease. Virology 2000; 269(2): 335-344. [PubMed: 10753712]

Kawana Y, Kawana K, Yoshikawa H, Taketani Y, Yoshiike K, Kanda T. Human papillomavirus type 16 minor capsid protein $12 \mathrm{~N}$-terminal region containing a common neutralization epitope binds to the cell surface and enters the cytoplasm. J Virol 2001; 75(5): 2,331-2,336. [PubMed: 11160736] 
Kaye KM, Izumi KM, Kieff E. Epstein-Barr virus latent membrane protein 1 is essential for B-lymphocyte growth transformation. Proc Natl Acad Sci USA 1993; 90(19): 9150-9154. [PubMed: 8415670]

Kaye K, Devergne O, Harada J, Izumi K, Yalamanchili R, Kieff E, Mosialos G. Tumor necrosis factor receptor associated factor 2 is a mediator of NF- $\kappa \mathrm{B}$ activation by latent infection membrane protein 1, the EpsteinBarr virus transforming protein. Proc Natl Acad Sci USA 1996; 93: 11,085-11,090. [PubMed: 8855313]

Kazanji M, Dussart P, Duprez R, Tortevoye P, Pouliquen JF, Vandekerkhove J, Couppie P, Morvan J, Talarmin A, Gessain A. Serological and molecular evidence that human herpesvirus 8 is endemic among Amerindians in French Guiana. J Infect Dis 2005; 192(9): 1,525-1,529. [PubMed: 16206066]

Kelekar A, Cole MD. Tumorigenicity of fibroblast lines expressing the adenovirus E1a, cellular p53, or normal c-myc genes. Mol Cell Biol 1986; 6(1): 7-14. [PubMed: 2946931]

Kieff, E. Epstein-Barr virus and its replication. In: Fields, BN.; Knipe, DM.; Howley, PM., editors. Virology. 3rd edn.. Lippinscott-Raven Publishers; Philadelphia, PA: 1996. p. 2,343-2,396.

Kilger E, Kieser A, Baumann M, Hammerschmidt W. Epstein-Barr virus-mediated B-cell proliferation is dependent upon latent membrane protein 1, which simulates an activated CD40 receptor. EMBO J 1998; 17: 1,700-1,709. [PubMed: 9501091]

Kirk O, Pedersen C, Cozzi-Lepri A, Antunes F, Miller V, Gatell JM, Katlama C, Lazzarin A, Skinhoj P, Barton SE. Non-Hodgkin lymphoma in HIV-infected patients in the era of highly active antiretroviral therapy. Blood 2001; 98(12): 3,406-3,412. [PubMed: 11719381]

Klaskala W, Brayfield BP, Kankasa C, Bhat G, West JT, Mitchell CD, Wood C. Epidemiological characteristics of human herpesvirus-8 infection in a large population of antenatal women in Zambia. J Med Virol 2005; 75(1): 93-100. [PubMed: 15543582]

Klencke BJ, Palefsky JM. Anal cancer: An HIV-associated cancer. Hematol Oncol Clin North Am 2003; 17(3): 859-872. [PubMed: 12852659]

Klepp O, Dahl O, Stenwig JT. Association of Kaposi's sarcoma and prior immunosuppressive therapy: A 5-year material of Kaposi's sarcoma in Norway. Cancer 1978; 42(6): 2,626-2,630. [PubMed: 728865]

Kliche S, Nagel W, Kremmer E, Atzler C, Ege A, Knorr T, Koszinowski U, Kolanus W, Haas J. Signaling by human herpesvirus 8 kaposin A through direct membrane recruitment of cytohesin-1. Mol Cell 2001; 7(4): 833-843. [PubMed: 11336706]

Knowles DM. Etiology and pathogenesis of AIDS-related non-Hodgkin's lymphoma. Hematol Oncol Clin North Am 2003; 17(3): 785-820. [PubMed: 12852656]

Kohl NE, Ruley HE. Role of c-myc in the transformation of REF52 cells by viral and cellular oncogenes. Oncogene 1987; 2(1): 41-48. [PubMed: 2830582]

Koutsky L. Epidemiology of genital human papillomavirus D. infection. Am J Med 1997; 102(5A): 3-8. [PubMed: 9217656]

Krithivas A, Young B, Liao G, Greene D, Hayward SD. Human herpesvirus 8 LANA interacts with proteins of the mSin 3 corepressor complex and negatively regulates Epstein-Barr virus gene expression in dually infected PEL cells. J Virol 2000; 74(20): 9,637-9,645. [PubMed: 11000236]

KuoSR, Liu JS, Broker TR, Chow LT. Cell-free replication of the human papillomavirus DNA with homologous viral E1 and E2 proteins and human cell extracts. J Biol Chem 1994; 269(39): 24,058-24,065. [PubMed: 7523366]

Lacoste V, Judde JG, Bestett G, Cadranel J, Antoine M, Valensi F, Delabesse E, Macintyre E, Gessain A. Virological and molecular characterisation of a new B lymphoid cell line, established from an AIDS patient with primary effusion lymphoma, harbouring both KSHV/HHV8 and EBV viruses. Leuk Lymphoma 2000; 38(34): 401-409. [PubMed: 10830748]

Lagunoff M, Ganem D. The structure and coding organization of the genomic termini of Kaposi's sarcomaassociated herpesvirus. Virology 1997; 236(1): 147-154. [PubMed: 9299627]

Lagunoff M, Majeti R, Weiss A, Ganem D. Deregulated signal transduction by the K1 gene product of Kaposi's sarcoma-associated herpesvirus. Proc Natl Acad Sci USA 1999; 96(10): 5,704-5,709. [PubMed: 10318948]

Langley CL, Benga-De E, Critchlow CW, Ndoye I, Mbengue-Ly MD, Kuypers J, Woto-Gaye G, Mboup S, Bergeron C, Holmes KK, Kiviat NB. HIV-1, HIV-2, human papillomavirus infection and cervical neoplasia in high-risk African women. AIDS 1996; 10(4): 413-417. [PubMed: 8728046] 
Laurence J. Repetitive and consistent cervicovaginal exposure to certain viral pathogens appears to protect against their sexual acquisition in some women: Potential mechanisms. J Reprod Immunol 2003; 58(1): 7991. [PubMed: 12609527]

Lazzi S, Ferrari F, Nyongo A, Palummo N, de Milito A, Zazzi M, Leoncini L, Luzi P, Tosi P. HIV-associated malignant lymphomas in Kenya (Equatorial Africa). Hum Pathol 1998; 29(11): 1,285- 1,289. [PubMed: 9824108]

Lee JK, Hurwitz J. Isolation and characterization of various complexes of the minichromosome maintenance proteins of Schizosaccharomyces pombe. J Biol Chem 2000; 275(25): 18,871-18,878. [PubMed: 10770926]

Lee H, Guo J, Li M, Choi JK, DeMaria M, Rosenzweig M, Jung JU. Identification of an immunoreceptor tyrosine-based activation motif of K1 transforming protein of Kaposi's sarcoma-associated herpesvirus. Mol Cell Biol 1998a; 18(9): 5,219-5,228. [PubMed: 9710606]

Lee H, Veazey R, Williams K, Li M, Guo J, Neipel F, Fleckenstein B, Lackner A, Desrosiers RC, Jung JU. Deregulation of cell growth by the K1 gene of Kaposi's sarcoma-associated herpesvirus. Natl Med 1998b; 4(4): 435-440. [PubMed: 9546789]

Lee BS, Connole M, Tang Z, Harris NL, Jung JU. Structural analysis of the Kaposi's sarcoma-associated herpesvirus K1 protein. J Virol 2003; 77(14): 8,072-8,086. [PubMed: 12829846]

Lennette ET, Blackbourn DJ, Levy JA. Antibodies to human herpesvirus type 8 in the general population and in Kaposi's sarcoma patients. Lancet 1996; 348(9031): 858-861. [PubMed: 8826812]

Levine AM. AIDS-related lymphoma. Semin Oncol Nurs 2006; 22(2): 80-89. [PubMed: 16720230]

Li JJ, Huang YQ, Cockerell CJ, Friedman-Kien AE. Localization of human herpes-like virus type 8 in vascular endothelial cells and perivascular spindle-shaped cells of Kaposi's sarcoma lesions by in situ hybridization. Am J Pathol 1996; 148(6): 1,741-1,748. [PubMed: 8669460]

Li M, Beard P, Estes PA, Lyon MK, Garcea RL. Intercapsomeric disulfide bonds in papillomavirus assembly and disassembly. J Virol 1998; 72(3): 2,160-2,167. [PubMed: 9499072]

Liang Y, Chang J, Lynch SJ, Lukac DM, Ganem D. The lytic switch protein of KSHV activates gene expression via functional interaction with RBP-Jkappa (CSL), the target of the Notch signaling pathway. Genes Dev 2002; 16(15): 1,977-1,989. [PubMed: 12154127]

Liebowitz D, Wang D, Kieff E. Orientation and patching of the latent infection membrane protein encoded by Epstein-Barr virus. J Virol 1986; 58(1): 233-237. [PubMed: 3005654]

Lillo FB, Ferrari D, Veglia F, Origoni M, Grasso MA, Lodini S, Mastrorilli E, Taccagni G, Lazzarin A, UbertiFoppa C. Human papillomavirus infection and associated cervical disease in human immunodeficiency virus-infected women: Effect of highly active antiretroviral therapy. J Infect Dis 2001; 184(5): 547-551. [PubMed: 11494160]

Londesborough P, Ho L, Terry G, Cuzick J, Wheeler C, Singer A. Human papillomavirus genotype as a predictor of persistence and development of high-grade lesions in women with minor cervical abnormalities. Int J Cancer 1996; 69(5): 364-368. [PubMed: 8900368]

Longnecker R. Epstein-Barr virus latency: LMP2, a regulator or means for Epstein-Barr virus persistence? Adv Cancer Res 2000; 79: 175-200. [PubMed: 10818681]

Longnecker R, Merchant M, Brown ME, Fruehling S, Bickford JO, Ikeda M, Harty RN. WW- and SH3domain interactions with Epstein-Barr virus LMP2A. Exp Cell Res 2000; 257(2): 332-340. [PubMed: 10837147]

Lopez Amado M, Castro Lareo I, LozanoRamirez A, Caballero Torcuato L. Epidemiology of otorhinolaryngological squamous cell papillomas in a Spanish subpopulation during a 20 year period. Rev Laryngol Otol Rhinol (Bord) 1996; 117(2): 105-110. [PubMed: 8959929]

Lothe F, Murray JF. Kaposi's sarcoma: Autopsy findings in the African. Acta Unio Int Contra Cancrum 1962; 18: 429-452. [PubMed: 14466781]

Mansky KC, Batiza A, Lambert PF. Bovine papillomavirus type $1 \mathrm{E} 1$ and simian virus 40 large T antigen share regions of sequence similarity required for multiple functions. J Virol 1997; 71(10): 7,600- 7,608. [PubMed: 9311841]

Mao C, Koutsky LA, Ault KA, Wheeler CM, Brown DR, Wiley DJ, Alvarez FB, Bautista OM, Jansen KU, Barr E. Efficacy of human papillomavirus-16 vaccine to prevent cervical intraepithelial neoplasia: A randomized controlled trial. Obstet Gynecol 2006; 107(1): 18-27. [PubMed: 16394035] 
Massad LS, Schneider MF, Watts DH, Strickler HD, Melnick S, Palefsky J, Anastos K, Levine AM, Minkoff $\mathrm{H}$. HPV testing for triage of HIV-infected women with papanicolaou smears read as atypical squamous cells of uncertain significance. J Womens Health (Larchmt) 2004; 13(2): 147-153. [PubMed: 15072728]

Mayama S, Cuevas LE, Sheldon J, Omar OH, Smith DH, Okong P, Silvel B, Hart CA, Schulz TF. Prevalence and transmission of Kaposi's sarcoma-associated herpesvirus (human herpesvirus 8) in Ugandan children and adolescents. Int J Cancer 1998; 77(6): 817-820. [PubMed: 9714046]

Mayaud P, Gill DK, Weiss HA, Uledi E, Kopwe L, Todd J, ka-Gina G, Grosskurth H, Hayes RJ, Mabey DC, Lacey CJ. The interrelation of HIV, cervical human papillomavirus, and neoplasia among antenatal clinic attenders in Tanzania. Sex Transm Infect 2001; 77(4): 248-254. [PubMed: 11463923]

Mbulaiteye SM, Biggar RJ, Goedert JJ, Engels EA. Pleural and peritoneal lymphoma among people with AIDS in the United States. J Acquir Immune Defic Syndr 2002; 29(4): 418-421. [PubMed: 11917248]

Mbulaiteye SM, Pfeiffer RM, Whitby D, Brubaker GR, Shao J, Biggar RJ. Human herpesvirus 8 infection within families in rural Tanzania. J Infect Dis 2003; 187(11): 1,780-1,785. [PubMed: 12751036]

McCormick C, Ganem D. Phosphorylation and function of the kaposin B direct repeats of Kaposi's sarcomaassociated herpesvirus. J Virol 2006; 80(12): 6,165-6,170. [PubMed: 16731955]

McGowan JP, Shah S. Long-term remission of AIDS-related primary central nervous system lymphoma associated with highly active antiretroviral therapy. AIDS 1998; 12(8): 952-954. [PubMed: 9631151]

Melbye M, Cook PM, Hjalgrim H, Begtrup K, Simpson GR, Biggar RJ, Ebbesen P, Schulz TF. Risk factors for Kaposi's-sarcoma-associated herpesvirus (KSHV/HHV-8) seropositivity in a cohort of homosexual men, 1981-1996. Int J Cancer 1998; 77(4): 543-548. [PubMed: 9679756]

Memar OM, Rady PL, Tyring SK. Human herpesvirus-8: Detection of novel herpesvirus-like DNA sequences in Kaposi's sarcoma and other lesions. J Mol Med 1995; 73(12): 603-609. [PubMed: 8825757]

Milde-Langosch KM, Loning T, Meichsner M, Henke RP. HPV infections in tumors of the upper respiratory and digestive tract. In situ hybridization and dot-blot hybridization with biotinylated DNA probes. Acta Histochem. Suppl 1989; 37: 103-108. [PubMed: 2549568]

Miller WE, Earp HS, Raab-Traub N. The Epstein-Barr virus latent membrane protein-1 induces expression of the epidermal growth factor receptor. J Virol 1995; 69: 4,390-4,398. [PubMed: 7769701]

Miller WE, Mosialos G, Kieff E, Raab-Traub N. Epstein-Barr virus LMP1 induction of the EGFR is mediated through a TRAF signaling pathway distinct from NF- $\kappa$ B activation. J Virol 1997; 71: 586- 594. [PubMed: 8985387]

Miller W, Cheshire J, Raab-Traub N. Interaction of tumor necrosis factor receptor-associated factor signaling proteins with the latent membrane protein 1 PXQXT motif is essential for induction of epidermal growth factor receptor expression. Mol Cell Biol 1998; 18: 2,835-2,844. [PubMed: 9566902]

Minchiotti S, Masucci L, Serapiao Dos Santos M, Perrella E, Graffeo R, Lambiase A, Bonini S. Conjunctival papilloma and human papillomavirus: Identification of HPV types by PCR. Eur J Ophthalmol 2006; 16(3): 473-477. [PubMed: 16761254]

Mincione GP, Taddei GL, Wolovsky M, Calzolari A, Mincione F. Detection of human papillomavirus (HPV) DNA type 6/11 in a conjunctival papilloma by in situ hybridization with biotinylated probes. Pathologica 1992; 84(1092): 483-488. [PubMed: 1337200]

Mineta H, Ogino T, Amano HM, Ohkawa Y, Araki K, Takebayashi S, Miura K. Human papilloma virus (HPV) type 16 and 18 detected in head and neck squamous cell carcinoma. Anticancer Res 1998; 18 (6B): 4,765-4,768. [PubMed: 9891554]

Minkoff H, Ahdieh L, Massad LS, Anastos K, Watts DH, Melnick S, Muderspach L, Burk R, Palefsky J. The effect of highly active antiretroviral therapy on cervical cytologic changes associated with oncogenic HPV among HIV-infected women. AIDS 2001; 15(16): 2,157-2,164. [PubMed: 11684935]

Mitchell T, Sugden B. Stimulation of NF- $\kappa$ B-mediated transcription by mutant derivatives of the latent membrane protein of Epstein-Barr virus. J Virol 1995; 69(5): 2,968-2,976. [PubMed: 7707523]

Molden J, Chang Y, You Y, Moore PS, Goldsmith MA. A Kaposi's sarcoma-associated herpesvirus-encoded cytokine homolog (vIL-6) activates signaling through the shared gp130 receptor subunit. J Biol Chem 1997; 
272(31): 19,625-19,631. [PubMed: 9235971]

Montaner S, Sodhi A, Molinolo A, Bugge TH, Sawai ET, He Y, Li Y, Ray PE, Gutkind JS. Endothelial infection with KSHV genes in vivo reveals that vGPCR initiates Kaposi's sarcomagenesis and can promote the tumorigenic potential of viral latent genes. Cancer Cell 2003; 3(1): 23-36. [PubMed: 12559173]

Moore, P.; Chang, Y. Kaposi's sacrcoma-associated herpesvirus. In: Knipe, DM., editor. Virology. Lippincott Williams \& Wilkins; Philadelphia, PA: 2001. p. 2,803-2,833.

Moore PS, Boshoff C, Weiss RA, Chang Y. Molecular mimicry of human cytokine and cytokine response pathway genes by KSHV. Science 1996a; 274(5293): 1,739-1,744. [PubMed: 8939871]

Moore PS, Gao SJ, Dominguez G, Cesarman E, Lungu O, Knowles DM, Garber R, Pellett PE, McGeoch DJ, Chang Y. Primary characterization of a herpesvirus agent associated with Kaposi's sarcomae. J Virol 1996b; 70(1): 549-558. [PubMed: 8523568]

Moore PS, Kingsley LA, Holmberg SD, Spira T, Gupta P, Hoover DR, Parry JP, Conley LJ, Jaffe HW, Chang Y. Kaposi's sarcoma-associated herpesvirus infection prior to onset of Kaposi's sarcoma. AIDS 1996c; 10(2): 175-180. [PubMed: 8838705]

Morison L. The global epidemiology of HIV/AIDS. Br Med Bull 2001; 58: 7-18. [PubMed: 11714621]

Moses AV, Fish KN, Ruhl R, Smith PP, Strussenberg JG, Zhu L, Chandran B, Nelson JA. Long-term infection and transformation of dermal microvascular endothelial cells by human herpesvirus 8. J Virol 1999; 73(8): 6,892-6,902. [PubMed: 10400787]

Mosunjac MB, Tadros T, Beach R, Majmudar B. Cervical schistosomiasis, human papilloma virus (HPV), and human immunodeficiency virus (HIV): A dangerous coexistence or coincidence? Gynecol Oncol 2003; 90(1): 211-214. [PubMed: 12821368]

Motti PG, Dallabetta GA, Daniel RW, Canner JK, Chiphangwi JD, Liomba GN, Yang L, Shah KV. Cervical abnormalities, human papillomavirus, and human immunodeficiency virus infections in women in Malawi. J Infect Dis 1996; 173(3): 714-717. [PubMed: 8627037]

Mueller N. Overview of the epidemiology of malignancy in immune deficiency. J Acquir Immune Defic Syndr 1999; 21(Suppl 1): S5-S10. [PubMed: 10430211]

Munger K, Phelps WC, Bubb V, Howley PM, Schlegel R. The E6 and E7 genes of the human papillomavirus type 16 together are necessary and sufficient for transformation of primary human keratinocytes. J Virol 1989; 63(10): 4,417-4,421. [PubMed: 2476573]

Munoz N, Bosch FX, Castellsague X, Diaz M, de Sanjose S, Hammouda D, Shah KV, Meijer CJ. Against which human papillomavirus types shall we vaccinate and screen? The international perspective. Int J Cancer 2004; 111(2): 278-285. [PubMed: 15197783]

Muralidhar S, Pumfery AM, Hassani M, Sadaie MR, Kishishita M, Brady JN, Doniger J, Medveczky P, Rosenthal LJ. Identification of kaposin (open reading frame K12) as a human herpesvirus 8 (Kaposi's sarcoma-associated herpesvirus) transforming gene. J Virol 1998; 72(6): 4,980-4,988. [PubMed: 9573267]

Muralidhar S, Veytsmann G, Chandran B, Ablashi D, Doniger J, Rosenthal LJ. Characterization of the human herpesvirus 8 (Kaposi's sarcoma-associated herpesvirus) oncogene, kaposin (ORF K12). J Clin Virol 2000; 16(3): 203-213. [PubMed: 10738139]

Nador RG, Cesarman E, Chadburn A, Dawson DB, Ansari MQ, Sald J, Knowles DM. Primary effusion lymphoma: A distinct clinicopathologic entity associated with the Kaposi's sarcoma-associated herpes virus. Blood 1996; 88(2): 645-656. [PubMed: 8695812]

Nakano K. Characteristics of human papillomavirus (HPV) infection in papilloma of the head and neck - detection of HPV according to clinical features and type specificity in the head and neck. Nippon Jibiinkoka Gakkai Kaiho 1994; 97(8): 1,381-1,392. [PubMed: 7931794]

Nakano K, Isegawa Y, Zou P, Tadagaki K, Inagi R, Yamanishi K. Kaposi's sarcoma-associated herpesvirus (KSHV)-encoded vMIP-I and vMIP-II induce signal transduction and chemotaxis in monocytic cells. Arch Virol 2003; 148(5): 871-890. [PubMed: 12721796]

Navarro WH, Kaplan LD. AIDS-related lymphoproliferative disease. Blood 2006; 107(1): 13-20. [PubMed: 16099881] 
Newell ME, Hoy JF, Cooper SG, DeGraaff B, Grulich AE, Bryant M, Millar JL, Brew BJ, Quinn DI. Human immunodeficiency virus-related primary central nervous system lymphoma: Factors influencing survival in 111 patients. Cancer 2004; 100(12): 2,627-2,636. [PubMed: 15197806]

Newton R, Ziegler J, Ateenyi-Agaba C, Bousarghin L, Casabonne D, Beral V, Mbidde E, Carpenter L, Reeves G, Parkin DM, Wabinga H, Mbulaiteye S, et al. The epidemiology of conjunctival squamous cell carcinoma in Uganda. Br J Cancer 2002; 87(3): 301-308. [PubMed: 12177799]

Nicholas J, Ruvolo VR, Burns WH, Sandford G, Wan X, Ciufo D, Hendrickson SB, Guo HG, Hayward GS, Reitz MS. Kaposi's sarcoma-associated human herpesvirus-8 encodes homologues of macrophage inflammatory protein-1 and interleukin-6. Natl Med 1997; 3(3): 287-292. [PubMed: 9055855]

Noy A. Update in HIV lymphoma. Curr Opin Oncol 2006; 18(5): 449-455. [PubMed: 16894292]

Nzila N, Laga M, Thiam MA, Mayimona K, Edidi B, Van Dyck E, Behets F, Hassig S, Nelson A, Mokwa K, et al. HIV and other sexually transmitted diseases among female prostitutes in Kinshasa. AIDS 1991; 5(6): 715-721. [PubMed: 1883543]

O'Farrell N, Hoosen AA, Kharsany AB, van den Ende J. Sexually transmitted pathogens in pregnant women in a rural South African community. Genitourin Med 1989; 65(4): 276-280. [PubMed: 2807289]

Oettle AG. Geographical and racial differences in the frequency of Kaposi's sarcoma as evidence of environmental or genetic causes. Acta Unio Int Contra Cancrum 1962; 18: 330-363. [PubMed: 14481196]

Olsen SJ, Chang Y, Moore PS, Biggar RJ, Melbye M. Increasing Kaposi's sarcoma-associated herpesvirus seroprevalence with age in a highly Kaposi's sarcoma endemic region, Zambia in 1985. AIDS 1998; 12(14): 1,921-1,925. [PubMed: 9792393]

Ong CK, Chan SY, Campo MS, Fujinaga K, Mavromara-Nazos P, Labropoulou V, Pfister H, Tay SK, Meulen J, Villa LL, et al. Evolution of human papillomavirus type 18: An ancient phylogenetic root in Africa and intratype diversity reflect coevolution with human ethnic groups. J Virol 1993; 67 (11): 6,424-6,431. [PubMed: 8411344]

Pagano JS. Epstein-Barr virus: The first human tumor virus and its role in cancer. Proc Assoc Am Physicians 1999; 111: 573-580. [PubMed: 10591086]

Palefsky J. Human papillomavirus infection among HIV-infected individuals. Implications for development of malignant tumors. Hematol Oncol Clin North Am 1991; 5(2): 357-370. [PubMed: 1850727]

Palefsky JM. Cervical human papillomavirus infection and cervical intraepithelial neoplasia in women positive for human immunodeficiency virus in the era of highly active antiretroviral therapy. Curr Opin Oncol 2003; 15(5): 382-388. [PubMed: 12960521]

Palefsky JM, Barrasso R. HPV infection and disease in men. Obstet Gynecol Clin North Am 1996; 23 (4): 895916. [PubMed: 8989780]

Pantanowitz L, Schlecht HP, Dezube BJ. The growing problem of non-AIDS-defining malignancies in HIV. Curr Opin Oncol 2006; 18(5): 469-478. [PubMed: 16894295]

Parkin DM, Garcia-Giannoli H, Raphael M, Martin A, Katangole-Mbidde E, Wabinga H, Ziegler J. NonHodgkin lymphoma in Uganda: A case-control study. AIDS 2000; 14(18): 2,929-2,936. [PubMed: 11153674]

Patil P, Elem B, Zumla A. Pattern of adult malignancies in Zambia (1980-1989) in light of the human immunodeficiency virus type 1 epidemic. J Trop Med Hyg 1995; 98(4): 281-284. [PubMed: 7636927]

Pellett PE, Wright DJ, Engels EA, Ablashi DV, Dollard SC, Forghani B, Glynn SA, Goedert JJ, Jenkins FJ, Lee TH, Neipel F, Todd DS, et al. Multicenter comparison of serologic assays and estimation of human herpesvirus 8 seroprevalence among US blood donors. Transfusion 2003; 43(9): 1,260- 1,268. [PubMed: 12919429]

Penn I. Kaposi's sarcoma in organ transplant recipients: Report of 20 cases. Transplantation 1979; 27(1): 8-11. [PubMed: 442191]

Peyton CL, Gravitt PE, Hunt WC, Hundley RS, Zhao M, Apple RJ, Wheeler CM. Determinants of genital human papillomavirus detection in a US population. J Infect Dis 2001; 183(11): 1,554-1,564. [PubMed: 11343204]

Piketty C, Darragh TM, Da Costa M, Bruneval P, Heard I, Kazatchkine MD, Palefsky JM. High prevalence of 
anal human papillomavirus infection and anal cancer precursors among HIV-infected persons in the absence of anal intercourse. Ann Intern Med 2003; 138(6): 453-459. [PubMed: 12639077]

Piketty C, Darragh TM, Heard I, Da Costa M, Bruneval P, Kazatchkine MD, Palefsky JM. High prevalence of anal squamous intraepithelial lesions in HIV-positive men despite the use of highly active antiretroviral therapy. Sex Transm Dis 2004; 31(2): 96-99. [PubMed: 14743072]

Plancoulaine S, Abel L, van Beveren M, Tregouet DA, Joubert M, Tortevoye P, de The G, Gessain A. Human herpesvirus 8 transmission from mother to child and between siblings in an endemic population. Lancet 2000; 356(9235): 1,062-1,065. [PubMed: 11009141]

Plancoulaine S, Abel L, Tregouet D, Duprez R, van Beveren M, Tortevoye P, Froment A, Gessain A. Respective roles of serological status and blood specific antihuman herpesvirus 8 antibody levels in human herpesvirus 8 intrafamilial transmission in a highly endemic area. Cancer Res 2004; 64 (23): 8,782-8,787. [PubMed: 15574792]

Ponten J, Guo Z. Precancer of the human cervix. Cancer Surv 1998; 32: 201-229. [PubMed: 10489629]

Prakash O, Tang ZY, Peng X, Coleman R, Gill J, Farr G, Samaniego F. Tumorigenesis and aberrant signaling in transgenic mice expressing the human herpesvirus-8 K1 gene. J Natl Cancer Inst 2002; 94(12): 926-935. [PubMed: 12072546]

Quinlivan EB, Zhang C, Stewart PW, Komoltri C, Davis MG, Wehbie RS. Elevated virus loads of Kaposi's sarcoma-associated human herpesvirus 8 predict Kaposi's sarcoma disease progression, but elevated levels of human immunodeficiency virus type 1 do not. J Infect Dis 2002; 185(12): 1,736-1,744. [PubMed: 12085319]

Rabkin CS, Schulz TF, Whitby D, Lennette ET, Magpantay LI, Chatlynne L, Biggar RJ, HHV-8 Interlaboratory Collaborative Groups. Interassay correlation of human herpesvirus 8 serologic tests. J Infect Dis 1998; 178(2): 304-309. [PubMed: 9697708]

Radkov SA, Kellam P, Boshoff C. The latent nuclear antigen of Kaposi sarcoma-associated herpesvirus targets the retinoblastoma-E2F pathway and with the oncogene Hras transforms primary rat cells. Natl Med 2000; 6(10): 1121-1127. [PubMed: 11017143]

Ralston R. Complementation of transforming domains in E1a/myc chimaeras. Nature 1991; 353(6347): 866868. [PubMed: 1834947]

Reszec J, Sulkowski S. The expression of P53 protein and infection of human papilloma virus in conjunctival and eyelid neoplasms. Int J Mol Med 2005; 16(4): 559-564. [PubMed: 16142387]

Center for Infectious Diseases. Council of State and Territorial Epidemiologists AIDS Program. MMWR Morb Mortal Wkly Rep 1987; 36(Suppl 1): 1S-15S. Revision of the CDC surveillance case definition for acquired immunodeficiency syndrome.

Rickinson, AB.; Kieff, E. Epstein-Barr Virus. In: Fields, BN.; Knipe, DM.; Howley, PM., editors. Virology. 3rd ed. Lippinscott-Raven Publishers; Philadelphia, PA: 1996. p. 2,397-2,446.

Roizmann B, Desrosiers RC, Fleckenstein B, Lopez C, Minson AC, Studdert MJ. The family herpesviridae: An update. The herpesvirus study group of the international committee on taxonomy of viruses. Arch Virol 1992; 123(34): 425-449. [PubMed: 1562239]

Russo JJ, Bohenzky RA, Chien MC, Chen J, Yan M, Maddalena D, Parry JP, Peruzzi D, Edelman IS, Chang Y, Moore PS. Nucleotide sequence of the Kaposi sarcoma-associated herpesvirus (HHV8). Proc Natl Acad Sci USA 1996; 93(25): 14,862-14,867. [PubMed: 8962146]

Sadler R, Wu L, Forghani B, Renne R, Zhong W, Herndier B, Ganem D. A complex translational program generates multiple novel proteins from the latently expressed kaposin (K12) locus of Kaposi's sarcomaassociated herpesvirus. J Virol 1999; 73(7): 5,722-5,730. [PubMed: 10364323]

Sakai H, Yasugi T, Benson JD, Dowhanick JJ, Howley PM. Targeted mutagenesis of the human papillomavirus type 16 E2 transactivation domain reveals separable transcriptional activation and DNA replication functions. J Virol 1996; 70(3): 1,602-1,611. [PubMed: 8627680]

Sandberg M, Hammerschmidt W, Sugden B. Characterizarion of LMP1's association with TRAF1, TRAF2, and TRAF3. J Virol 1997; 71: 4,649-4,656. [PubMed: 9151858]

Sapp M, Perez-Ordonez B, Brenneman F, Imrie K, Morava-Protzner I, Lim MS. EBV-associated perianal Hodgkin's disease in an HIV-positive individual. Am J Hematol 2001; 66(1): 42-45. [PubMed: 11426491] 
Schuman P, Ohmit SE, Klein RS, Duerr A, Cu-Uvin S, Jamieson DJ, Anderson J, Shah KV. Longitudinal study of cervical squamous intraepithelial lesions in human immunodeficiency virus (HIV)seropositive and atrisk HIV-seronegative women. J Infect Dis 2003; 188(1): 128-136. [PubMed: 12825181]

Schwarz E, Freese UK, Gissmann L, Mayer W, Roggenbuck B, Stremlau A, zur Hausen H. Structure and transcription of human papillomavirus sequences in cervical carcinoma cells. Nature 1985; 314 (6006): 111114. [PubMed: 2983228]

Sedman J, Stenlund A. Co-operative interaction between the initiator E1 and the transcriptional activator E2 is required for replicator specific DNA replication of bovine papillomavirus in vivo and in vitro. EMBO J 1995; 14(24): 6,218-6,228. [PubMed: 8557041]

Seif I. Sequence homology between the large tumor antigen of polyoma viruses and the putative E1 protein of papilloma viruses. Virology 1984; 138(2): 347-352. [PubMed: 6093371]

Serwadda D, Wawer MJ, Shah KV, Sewankambo NK, Daniel R, Li C, Lorincz A, Meehan MP, Wabwire-Mangen F, Gray RH. Use of a hybrid capture assay of self-collected vaginal swabs in rural Uganda for detection of human papillomavirus. J Infect Dis 1999; 180(4): 1,316-1,319. [PubMed: 10479163]

Shalloway D, Johnson PJ, Freed EO, Coulter D, Flood WA Jr. Transformation of NIH 3T3 cells by cotransfection with c-src and nuclear oncogenes. Mol Cell Biol 1987; 7(10): 3,582-3,590. [PubMed: 2446117]

Shaw, KV.; Howley, PM. Papillomavirinae: The viruses and their replication. In: Knipe, DM.; Howley, PM.; Griffin, DE.; Lamb, RA.; Martin, MA., editors. Fields Virology. 4th ed. Lippincott Williams \& Wilkins; Philadelphia, PA: 2001.

Shibata D, Weiss LM, Hernandez AM, Nathwani BN, Bernstein L, Levine AM. Epstein-Barr virus-associated non-Hodgkin's lymphoma in patients infected with the human immunodeficiency virus. Blood 1993; 81(8): 2,102-2,109. [PubMed: 8386027]

Silverberg MJ, Ahdieh L, Munoz A, Anastos K, Burk RD, Cu-UvinS, Duerr A, Greenblatt RM, Klein RS, Massad $\mathrm{S}$, Minkoff H, Muderspach L, et al. The impact of HIV infection and immunodeficiency on human papillomavirus type 6 or 11 infection and on genital warts. Sex Transm Dis 2002; 29(8): 427-435. [PubMed:12172526]

Simpson GR, Schulz TF, Whitby D, Cook PM, Boshoff C, Rainbow L, Howard MR, Gao SJ, Bohenzky RA, Simmonds P, Lee C, de Ruiter A, et al. Prevalence of Kaposi's sarcoma associated herpesvirus infection measured by antibodies to recombinant capsid protein and latent immunofluorescence antigen. Lancet 1996; 348(9035): 1,133-1,138. [PubMed: 8888167]

Sinclair KA, Woods CR, Kirse DJ, Sinal SH. Anogenital and respiratory tract human papillomavirus infections among children: Age, gender, and potential transmission through sexual abuse. Pediatrics 2005; 116(4): 815-825. [PubMed: 16199688]

Sirera G, Videla S, Pinol M, Canadas MP, Llatjos M, Ballesteros AL, Garcia-Cuyas F, Castella E, Guerola R, Tural C, Rey-Joly C, Clotet B. High prevalence of human papillomavirus infection in the anus, penis and mouth in HIV-positive men. AIDS 2006; 20(8): 1,201-1,204. [PubMed: 16691074]

Sodhi A, Montaner S, Patel V, Zohar M, Bais C, Mesri EA, Gutkind JS. The Kaposi's sarcoma-associated herpes virus $G$ protein-coupled receptor up-regulates vascular endothelial growth factor expression and secretion through mitogen-activated protein kinase and p38 pathways acting on hypoxia-inducible factor 1alpha. Cancer Res 2000; 60(17): 4,873-4,880. [PubMed: 10987301]

Soulier J, Grollet L, Oksenhendler E, Cacoub P, Cazals-Hatem D, Babinet P, d'Agay MF, Clauvel JP, Raphael M, Degos L. Kaposi's sarcoma-associated herpesvirus-like DNA sequences in multicentric Castleman's disease. Blood 1995; 86(4): 1,276-1,280. [PubMed: 7632932]

Sparano JA. Human immunodeficiency virus associated lymphoma. Curr Opin Oncol 2003; 15(5): 372- 378. [PubMed: 12960519]

Sparano JA, Anand K, Desai J, Mitnick RJ, Kalkut GE, Hanau LH. Effect of highly active antiretroviral therapy on the incidence of HIV-associated malignancies at an urban medical center. J Acquir Immune Defic Syndr 1999; 21(Suppl 1): S18-S22. [PubMed: 10430213]

St. Louis ME, Icenogle JP, Manzila T, Kamenga M, Ryder RW, Heyward WL, Reeves WC. Genital types of papillomavirus in children of women with HIV-1 infection in Kinshasa, Zaire. Int J Cancer 1993; 54(2): 181184. [PubMed: 8387461] 
Stauffer Y, Raj K, Masternak K, Beard P. Infectious human papillomavirus type 18 pseudovirions. J Mol Biol 1998; 283(3): 529-536. [PubMed: 9784363]

Strickler HD, Palefsky JM, Shah KV, Anastos K, Klein RS, Minkoff H, Duerr A, Massad LS, Celentano DD, Hall C, Fazzari M, Cu-Uvin S, et al. Human papillomavirus type 16 and immune status in human immunodeficiency virus-seropositive women. J Natl Cancer Inst 2003; 95(14): 1,062-1,071. [PubMed: 12865452]

Syrjanen S. Human papillomavirus infections and oral tumors. Med Microbiol Immunol (Berl.) 2003; 192(3): 123-128. [PubMed: 12920585]

Syrjanen S. Human papillomavirus (HPV) in head and neck cancer. J Clin Virol 2005; 32(Suppl 1):S59- S66. [PubMed: 15753013]

Tabrizi SN, McCurrach FE, Drewe RH, Borg AJ, Garland SM, Taylor HR. Human papillomavirus in corneal and conjunctival carcinoma. Aust NZ J Ophthalmol 1997; 25(3): 211-215. [PubMed: 9296295]

Tedeschi R, Dillner J, De Paoli P. Laboratory diagnosis of human herpesvirus 8 infection in humans. Eur J Clin Microbiol Infect Dis 2002; 21(12): 831-844. [PubMed: 12525917]

ter Meulen J, Eberhardt HC, Luande J, Mgaya HN, Chang-Claude J, Mtiro H, Mhina M, Kashaija P, Ockert S, Yu X, Meinhardt G, Gissmann L, et al. Human papillomavirus (HPV) infection, HIV infection and cervical cancer in Tanzania, east Africa. Int J Cancer 1992; 51(4): 515-521. [PubMed: 1318265]

Thomas JO. Acquired immunodeficiency syndrome-associated cancers in sub-Saharan Africa. Semin Oncol 2001; 28(2): 198-206. [PubMed: 11301383]

Thomas JO, Herrero R, Omigbodun AA, Ojemakinde K, Ajayi IO, Fawole A, Oladepo O, Smith JS, Arslan A, Munoz N, Snijders PJ, Meijer CJ, et al. Prevalence of papillomavirus infection in women in Ibadan, Nigeria: A population-based study. Br J Cancer 2004; 90(3): 638-645. [PubMed: 14760378]

Thome M, Schneider P, Hofmann K, Fickenscher H, Meinl E, Neipel F, Mattmann C, Burns K, Bodmer JL, Schroter M, Scaffidi C, Krammer PH, et al. Viral FLICE-inhibitory proteins (FLIPs) prevent apoptosis induced by death receptors. Nature 1997; 386(6624): 517-521. [PubMed: 9087414]

Tomkowicz B, Singh SP, Lai D, Singh A, Mahalingham S, Joseph J, Srivastava S, Srinivasan A. Mutational analysis reveals an essential role for the LXXLL motif in the transformation function of the human herpesvirus-8 oncoprotein, kaposin. DNA Cell Biol 2005; 24(1): 10-20. [PubMed: 15684715]

Touze A, El Mehdaoui S, Sizaret PY, Mougin C, Munoz N, Coursaget P. The L1 major capsid protein of human papillomavirus type 16 variants affects yield of virus-like particles produced in an insect cell expression system. J Clin Microbiol 1998; 36(7): 2,046-2,051. [PubMed: 9650960]

Trivedi P, Takazawa K, Zompetta C, Cuomo L, Anastasiadou E, Carbone A, Uccini S, Belardelli F, Takada K, Frati L, Faggioni A. Infection of HHV-8+ primary effusion lymphoma cells with a recombinant EpsteinBarr virus leads to restricted EBV latency, altered phenotype, and increased tumorigenicity without affecting TCL1 expression. Blood 2004; 103(1): 313-316. [PubMed: 12969959]

Update on acquired immune deficiency syndrome (AIDS) - United States. MMWR Morb Mortal Wkly Rep 1982; 31(37): 507-508. 513-504. [PubMed: 6815471]

Update: National Breast and Cervical Cancer Early Detection Program July 1991-July 1992. MMWR Morb Mortal Wkly Rep 1992; 41(40): 739-743. [PubMed: 1328839]

Villa LL, Costa RL, Petta CA, Andrade RP, Ault KA, Giuliano AR, Wheeler CM, Koutsky LA, Malm C, Lehtinen M, Skjeldestad FE, Olsson SE, et al. Prophylactic quadrivalent human papillomavirus (types 6, 11, 16, and 18) L1 virus-like particle vaccine in young women: A randomised double-blind placebo-controlled multi-centre phase II efficacy trial. Lancet Oncol 2005; 6(5): 271-278. [PubMed: 15863374]

von Krogh G, Wikstrom A, Syrjanen K, Syrjanen S. Anal and penile condylomas in HIV-negative and HIVpositive men: Clinical, histological and virological characteristics correlated to therapeutic outcome. Acta Derm Venereol 1995; 75(6): 470-474. [PubMed: 8651027]

Waddell KM, Lewallen S, Lucas SB, Atenyi-Agaba C, Herrington CS, Liomba G. Carcinoma of the conjunctiva and HIV infection in Uganda and Malawi. Br J Ophthalmol 1996; 80(6): 503-508. [PubMed: 8759259] 
Waddell K, Magyezi J, Bousarghin L, Coursaget P, Lucas S, Downing R, Casabonne D, Newton R. Antibodies against human papillomavirus type 16 (HPV-16) and conjunctival squamous cell neoplasia in Uganda. Br J Cancer 2003; 88(12): 2002-2003. [PubMed: 12799649]

Walboomers JM, Jacobs MV, Manos MM, Bosch FX, Kummer JA, Shah KV, Snijders PJ, Peto J, Meijer CJ, Munoz N. Human papillomavirus is a necessary cause of invasive cervical cancer worldwide. J Pathol 1999; 189(1): 12-19. [PubMed: 10451482]

Wang HW, Boshoff C. Linking Kaposi virus to cancer-associated cytokines. Trends Mol Med 2005; 11 (7): 309312. [PubMed: 15967719]

Wang D, Leibowitz D, Kieff E. An EBV membrane protein expressed in immortalized lymphocytes transforms established rodent cells. Cell 1985; 43: 831-840. [PubMed: 3000618]

Wang F, Gregory C, Sample C, Rowe M, Liebowitz D, Murray R, Rickinson A, Kieff E. Epstein-Barr virus latent membrane protein (LMP1) and nuclear proteins 2 and 3C are effectors of phenotypic changes in B lymphocytes: EBNA-2 and LMP1 cooperatively induce CD23. J Virol 1990; 64(5): 2309-2318. [PubMed: 2157887]

Weinberg RA. The action of oncogenes in the cytoplasm and nucleus. Science 1985; 230(4727): 770-776. [PubMed: 2997917]

Weinberg RA. Oncogenes, antioncogenes, and the molecular bases of multistep carcinogenesis. Cancer Res 1989; 49(14): 3,713-3,721. [PubMed: 2660980]

Whitby D, Howard MR, Tenant-Flowers M, Brink NS, Copas A, Boshoff C, Hatzioannou T, Suggett FE, Aldam DM, Denton AS, et al. Detection of Kaposi sarcoma associated herpesvirus in peripheral blood of HIV-infected individuals and progression to Kaposi's sarcoma. Lancet 1995; 346(8978): 799-802. [PubMed: 7674745]

Wilkinson D, Sheldon J, Gilks CF, Schulz TF. Prevalence of infection with human herpesvirus 8/Kaposi's sarcoma herpesvirus in rural South Africa. S Afr Med J 1999; 89(5): 554-557. [PubMed: 10416461]

Williams AB, Darragh TM, Vranizan K, Ochia C, Moss AR, Palefsky JM. Anal and cervical human papillomavirus infection and risk of anal and cervical epithelial abnormalities in human immunodeficiency virus-infected women. Obstet Gynecol 1994; 83(2): 205-211. [PubMed: 8290181]

Williamson AL, Brink NS, Dehaeck CM, Ovens S, Soeters R, Rybicki EP. Typing of human papillomaviruses in cervical carcinoma biopsies from Cape Town. J Med Virol 1994; 43(3): 231- 237. [PubMed: 7931183]

Williamson AL, Marais D, Passmore JA, Rybicki E. Human papillomavirus (HPV) infection in Southern Africa: Prevalence, immunity, and vaccine prospects. IUBMB Life 2002; 53(45): 253-258. [PubMed: 12121005]

Wood C, Harrington W Jr. AIDS and associated malignancies. Cell Res 2005; 15(1112): 947-952. [PubMed: 16354573]

Xi LF, Critchlow CW, Wheeler CM, Koutsky LA, Galloway DA, Kuypers J, Hughes JP, Hawes SE, Surawicz C, Goldbaum G, Holmes KK, Kiviat NB. Risk of anal carcinoma in situ in relation to human papillomavirus type 16 variants. Cancer Res 1998; 58(17): 3,839-3,844. [PubMed: 9731493]

Xi LF, Toure P, Critchlow CW, Hawes SE, Dembele B, Sow PS, Kiviat NB. Prevalence of specific types of human papillomavirus and cervical squamous intraepithelial lesions in consecutive, previously unscreened, West-African women over 35 years of age. Int J Cancer 2003; 103(6): 803-809. [PubMed: 12516102]

Xu D, Coleman T, Zhang J, Fagot A, Kotalik C, Zhao L, Trevidi P, Jones C, Zhang L. Epstein-Barr virus inhibits Kaposis sarcoma-associated herpesvirus lytic replication in primary effusion lymphomas. 2007 (submitted for publication)

Yang TY, Chen SC, Leach MW, Manfra D, Homey B, Wiekowski M, Sullivan L, Jenh CH, Narula SK, Chensue SW, Lira SA. Transgenic expression of the chemokine receptor encoded by human herpesvirus 8 induces an angioproliferative disease resembling Kaposi's sarcoma. J Exp Med 2000; 191(3): 445-454. [PubMed: 10662790] 
Yee C, Krishnan-Hewlett I, Baker CC, Schlegel R, Howley PM. Presence and expression of human papillomavirus sequences in human cervical carcinoma cell lines. Am J Pathol 1985a; 119(3): 361- 366. [PubMed: 2990217]

Yee C, Krishnan-Hewlett I, Baker CC, Schlegel R, Howley PM. Presence and expression of human papillomavirus sequences in human cervical carcinoma cell lines. Am J Pathol 1985b; 119(3): 361- 366. [PubMed: 2990217]

Yoshizaki T, Sato H, Furukawa M, Pagano JS. The expression of matrix metalloproteinase 9 is enhanced by Epstein-Barr virus latent membrane protein 1. Proc Natl Acad Sci USA 1998; 95: 3,621-3,626. [PubMed: 9520415]

Yoshpe NS. Oral and laryngeal papilloma: A pediatric manifestation of sexually transmitted disease? Int J Pediatr Otorhinolaryngol 1995; 31(1): 77-83. [PubMed: 7729997]

Zhang L, Pagano JS. Interferon regulatory factor 2 represses the Epstein-Barr virus BamH I Q latency promoter in type III latency. Mol Cell Biol 1999; 19: 3,216-3,223. [PubMed: 10082588]

Zhang J, Das SC, Kotalik C, Pattnaik AK, Zhang L. The latent membrane protein 1 of Epstein-Barr virus establishes an antiviral state via induction of interferon-stimulated genes. J Biol Chem 2004a; 279 (44): 46,33546,342. [PubMed: 15322136]

Zhang L, Hong K, Zhang J, Pagano J. Multiple signal transducers and activators of transcription (STATs) are induced by EBV LMP-1. Virology 2004b; 323: 141-152. [PubMed: 15165826]

Zhang L, Zhang J, Lambert Q, Der CJ, Del Valle L, Miklossy J, Khalili K, Zhou Y, Pagano JS. Interferon regulatory factor 7 is associated with Epstein-Barr virus-transformed central nervous system lymphoma and has oncogenic properties. J Virol 2004c; 78(23): 12,987-12,995. [PubMed: 15542650]

Zimber-Strobl U, Strobl LJ. EBNA2 and Notch signalling in Epstein-Barr virus mediated immortalization of B lymphocytes. Semin Cancer Biol 2001; 11(6): 423-434. [PubMed: 11669604]

Zippin C, Lum D. Study of completeness of the surveillance, epidemiology and end results (SEER) program case ascertainment by hospital size and casefinding source. Health Rep 1993; 5(1): 87-90. [PubMed: 8334243]

zur Hausen H. Papillomaviruses in human cancers. Proc Assoc Am Physic 1999; 111(6): 581-587.

zur Hausen H. Papillomaviruses causing cancer: Evasion from host-cell control in early events in carcinogenesis. J Natl Cancer Inst 2000; 92(9): 690-698. [PubMed: 10793105]

zur Hausen H, Gissmann L, Steiner W, Dippold W, Dreger I. Human papilloma viruses and cancer. Bibl Haematol 1975;(43): 569-571. [PubMed: 183728]

zur Hausen H, de Villiers EM, Gissmann L. Papillomavirus infections and human genital cancer. Gynecol Oncol 1981; 12(2 Pt 2):S124-128. [PubMed: 6273261] 


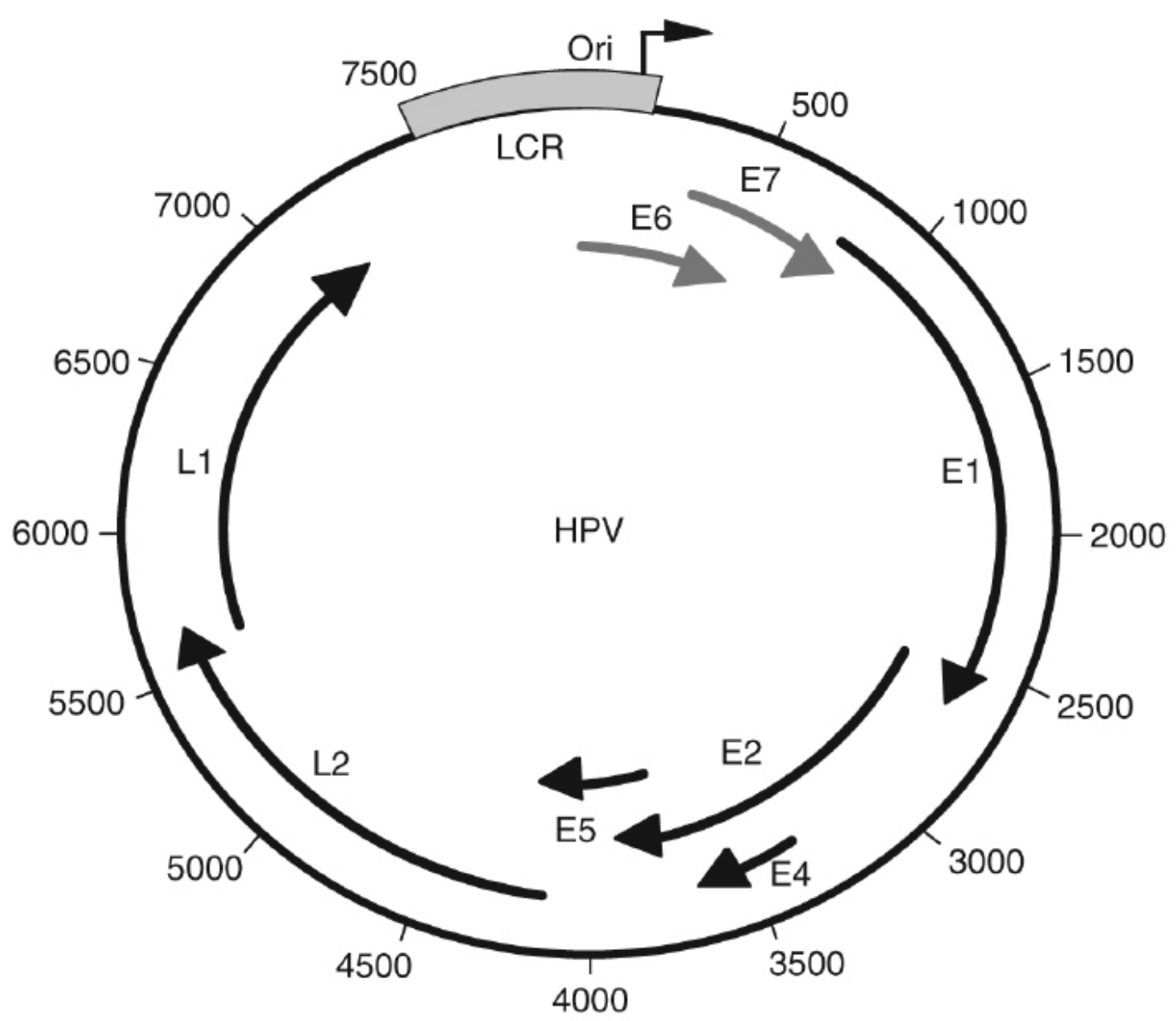

Figure 1.

The HPV genome is a $7.9 \mathrm{~kb}$ double-stranded circular genome. The genome is controlled by a single keratin-dependent promoter element; the long control region (LCR; in blue). At the 3'end of the LCR is the origin of replication (nucleotide position 1). E6, E7 (red), and E5 are viral oncogenes; E1 and E2 early genes encode replication proteins. The E4 ORF is actually expressed early and late in the viral life cycle. The late genes, L1 and L2, are the major and minor capsid genes, respectively. The viral protein functions are detailed in Table I. 


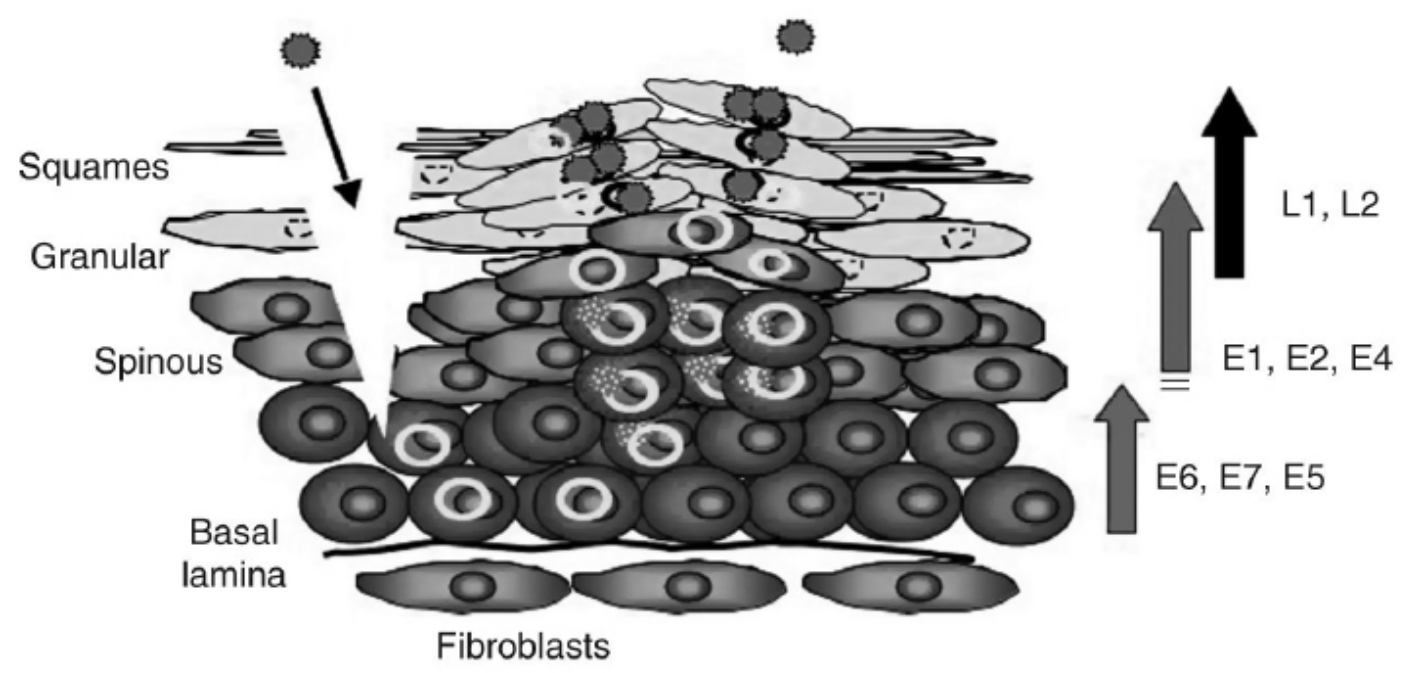

Figure 2.

The HPV life cycle. Virions enter the stratified epithelium through a site of wounding, where they gain access to the mitotically active basal-layer keratinocytes. During the maintenance phase, expression of E6, E7, and E5 induces cell proliferation, and the viral genome is replicated extrachromosomally at low-copy number (5-50 copies per cell). As the cells differentiate, the expression level of E1, E2, and E4 increases in the spinous layer. A transition from theta to rolling-circle replication results in an increase in copy number up to 100-1000 copies per cell. Postamplification, high levels of L1 and L2 capsid genes are expressed and capsid assembly occurs in the granular and squamous layers of the stratified epithelium. Progeny virus is released by desquamation. 


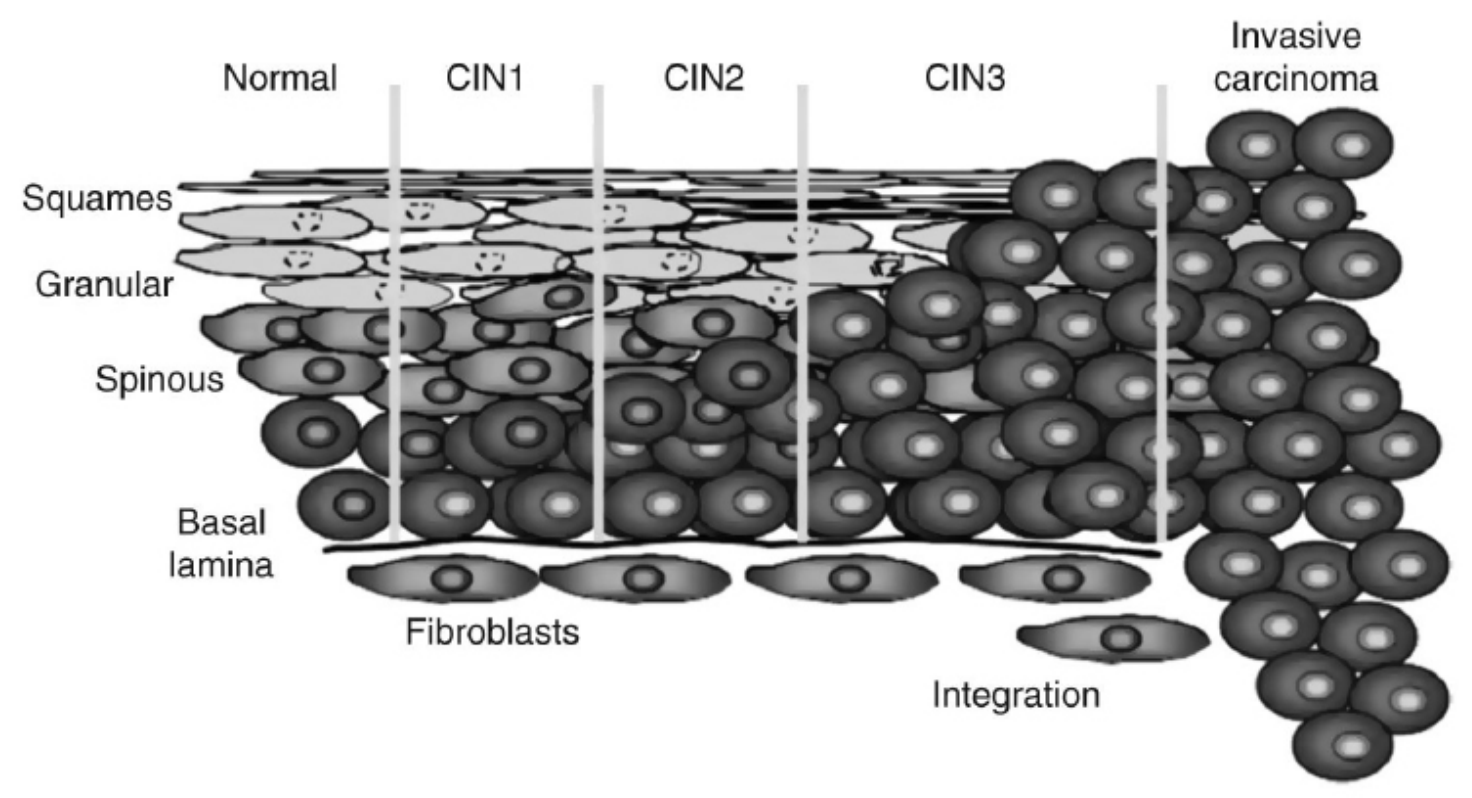

Figure 3.

Progression from a benign cervical lesion to invasive cervical cancer. In the diagram, HPV-positive cells are depicted by yellow nuclei. Infection by oncogenic HPV types, especially HPV16, can cause formation of a benign wart, low or high-grade dysplasia- r. CIN 1 and CIN 2 designations are reversible forms of precancerous lesions and CIN 3 is irreversible. Carcinoma in situ occurs many years after an infection. This results from the effects of HPV genes, particularly those encoding E6 and E7, which are the two viral oncoproteins that are preferentially retained and expressed in cervical cancers by integration of the viral DNA into the host genome. 

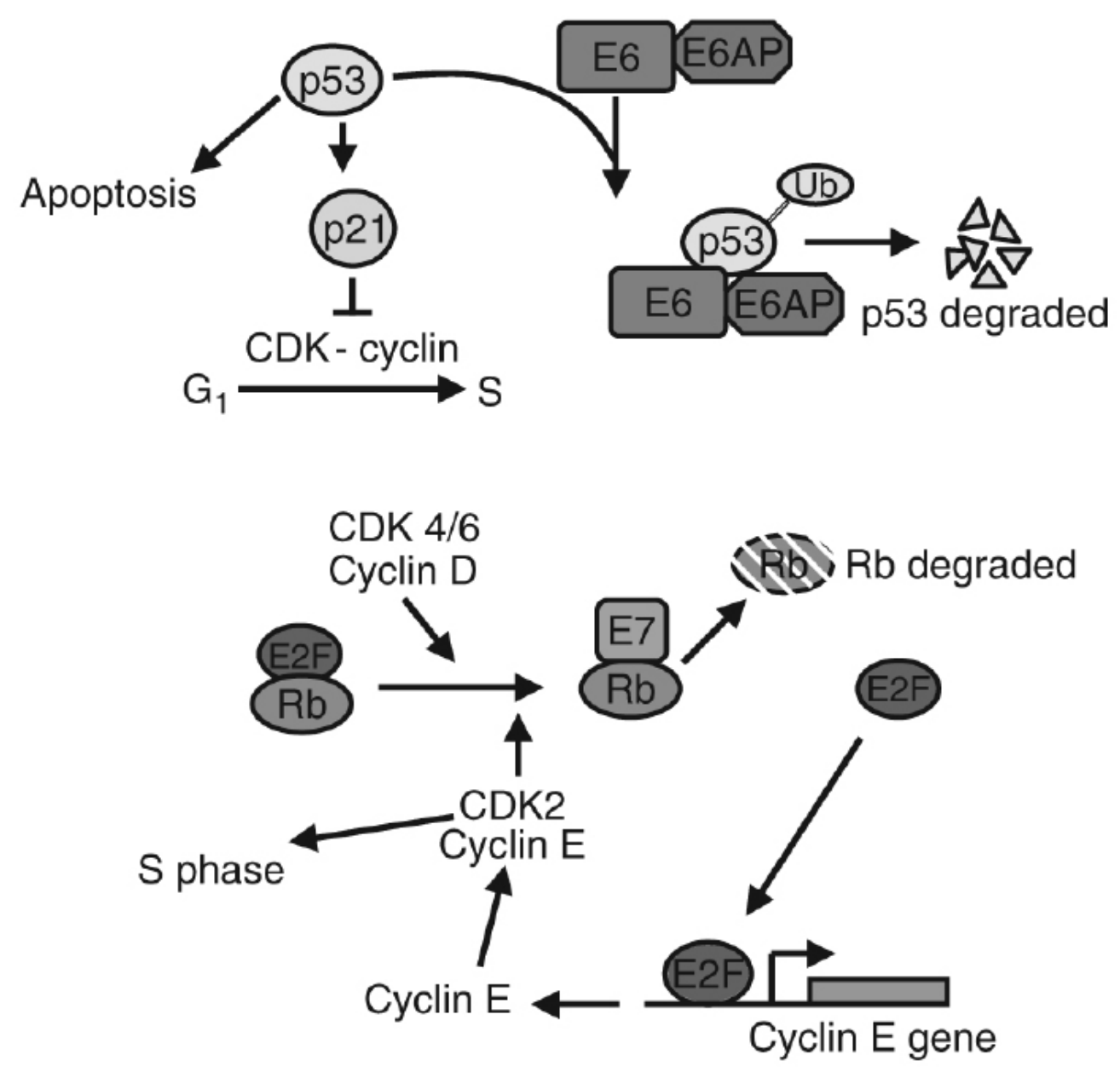

Figure 4 .

Diagram of the role of E6 and E7 in disregulation of the cell cycle. Expression of E6 leads to recruitment of E6AP (a ubiquitin ligase). This complex causes degradation of p53, which then inhibits the p21-dependent block of the G1 to S transition. Similarly, E7 binding to Rb displaces E2F, resulting in Rb's degradation. E2F can then activate expression of cyclin E and other S-phase related gene products. 


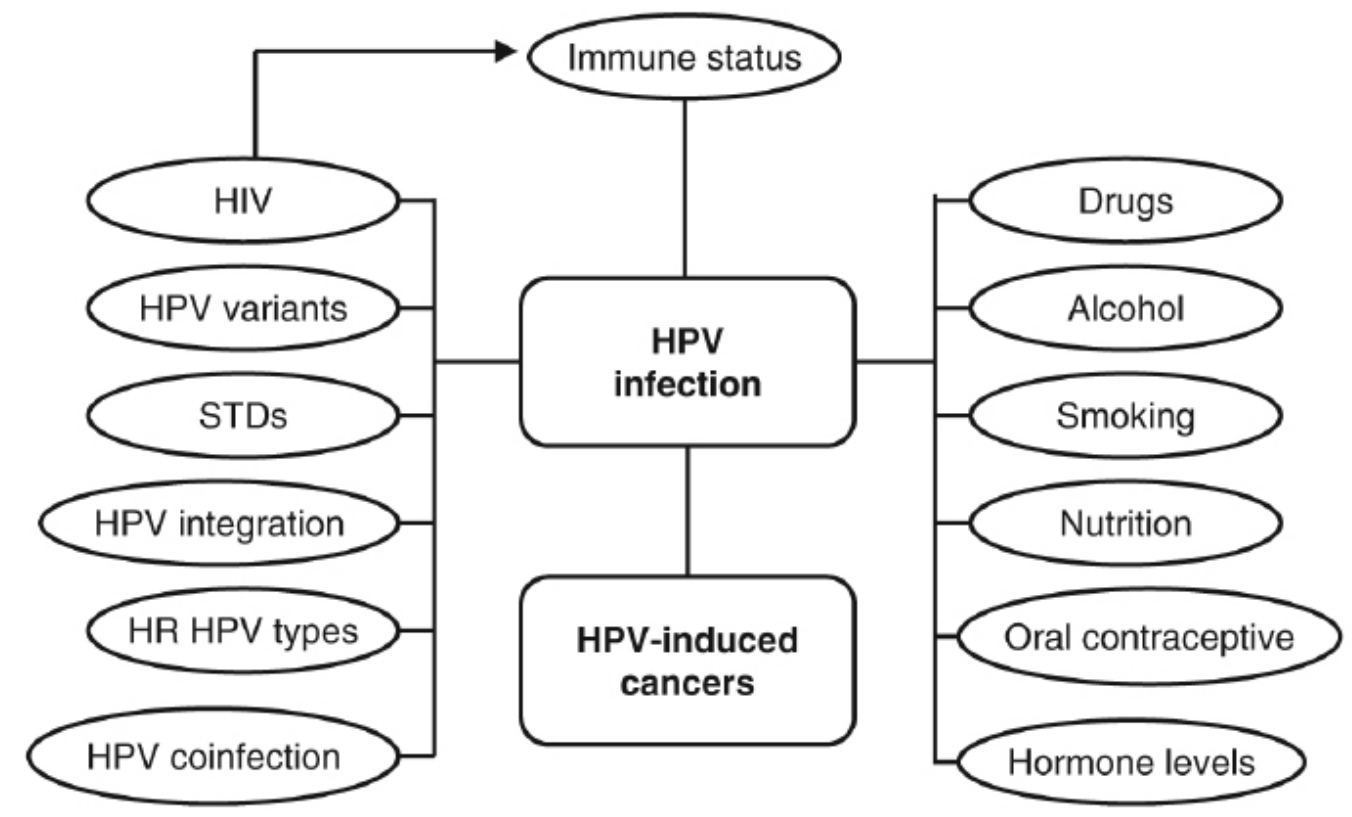

Figure 5.

The rate of advancement of HPV lesions, from benign hyperplasia to carcinoma in situ, is affected by additional factors, which includes immunocompetence. HIV status, alcohol, drugs, smoking, oral contraceptives, and hormone levels influence HPV infection and progression of HPV-induced cancers. High-risk HPVs, HPV coinfection, variants, genome integration, and infection of other STDs affect the propensity for HPV-induced cancer to occur and progress. 


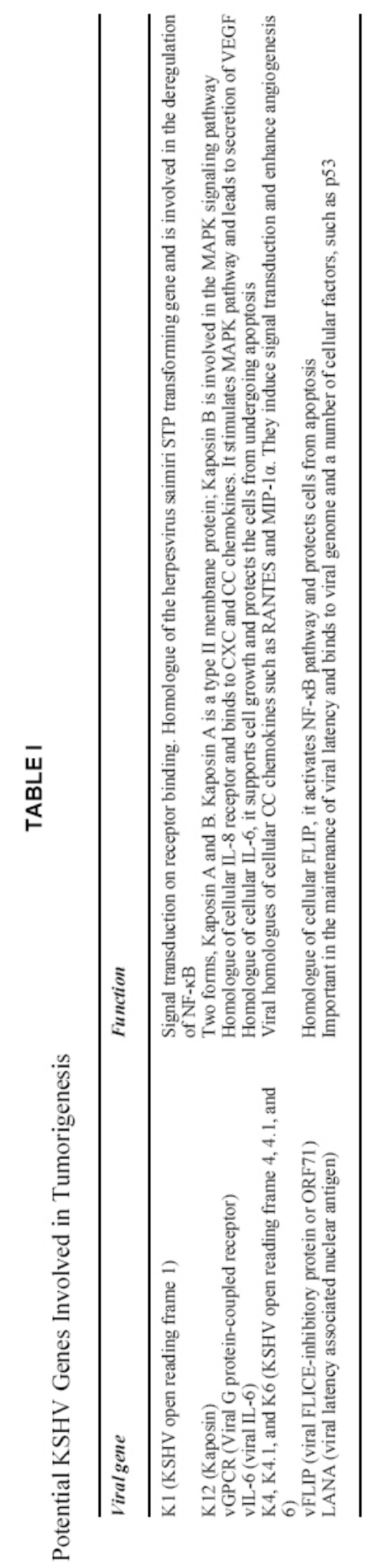




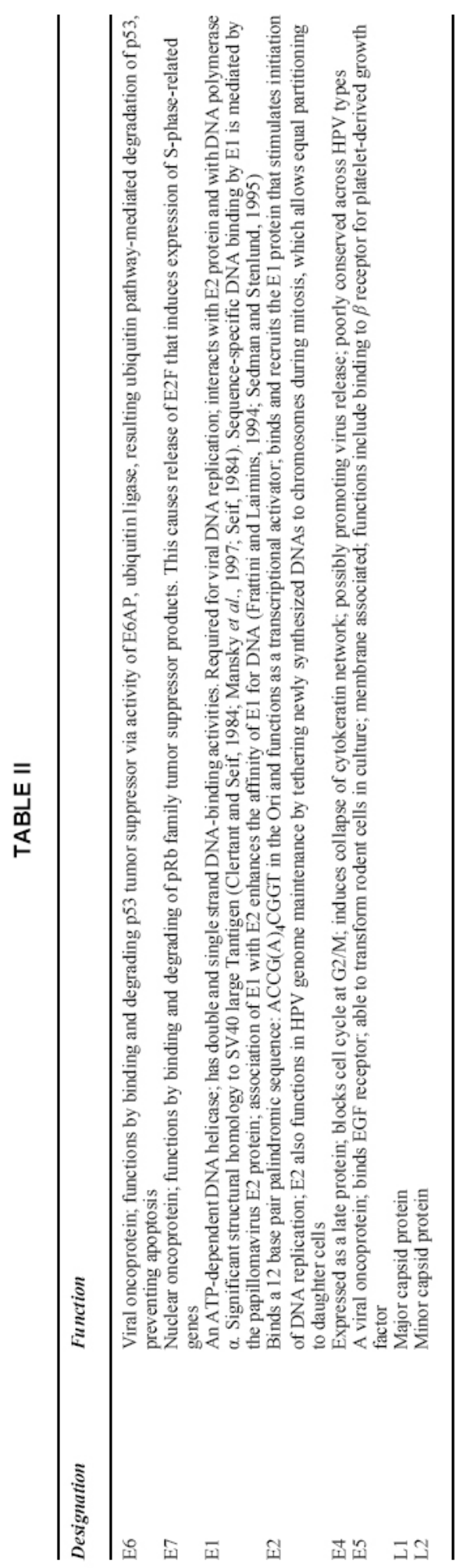

